\title{
WATER-LEVEL DATA FOR THE ALBUQUERQUE BASIN, NEW MEXICO, OCTOBER 1, 1986, THROUGH SEPTEMBER 30, 1990
}

By Dale R. Rankin

U.S. GEOLOGICAL SURVEY

Open-File Report 94-349

Prepared in cooperation with the CITY OF ALBUQUERQUE 


\section{U.S. DEPARTMENT OF THE INTERIOR \\ BRUCE BABBITT, Secretary \\ U.S. GEOLOGICAL SURVEY \\ Gordon P. Eaton, Director}

For additional information write to:

District Chief

U.S. Geological Survey Water Resources Division 4501 Indian School Rd. NE, Suite 200 Albuquerque, New Mexico 87110
Copies of this report can be purchased from:

U.S. Geological Survey Earth Science Information Center Open-File Reports Section Box 25286, MS 517 Denver Federal Center Denver, Colorado 80225 


\section{CONTENTS}

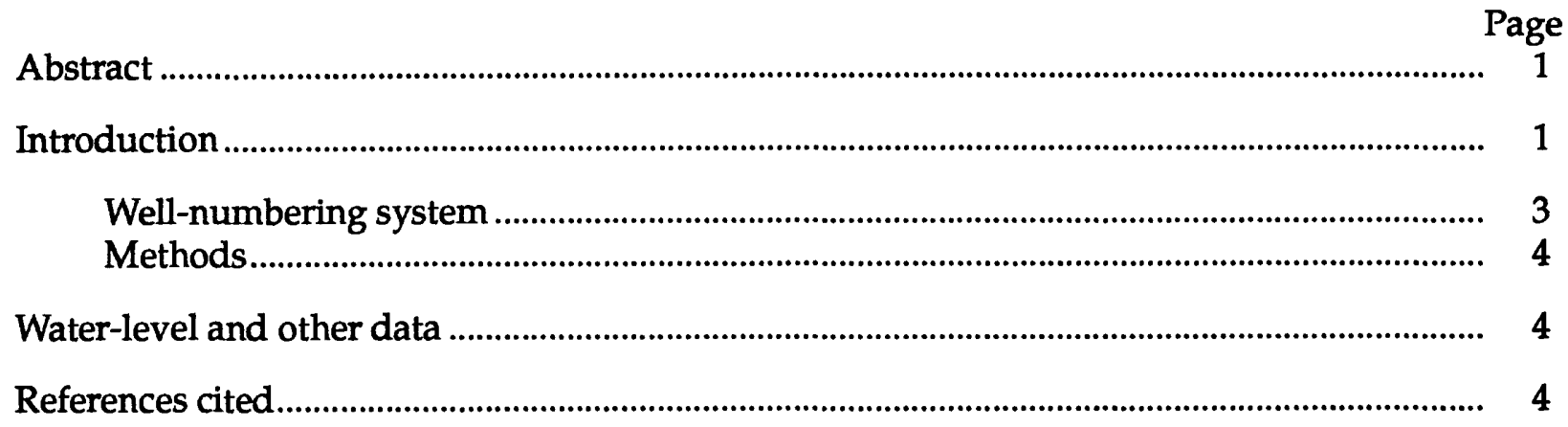

\section{FIGURES}

1. Map showing location of study area...................................................................................... 2

2. Diagram showing system of numbering wells in New Mexico............................................... 3

3. Hydrographs showing water-level data from selected wells and piezometers in the Albuquerque Basin:

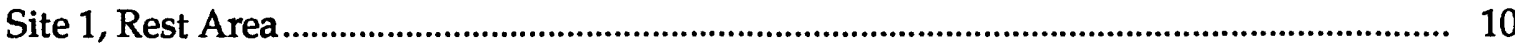

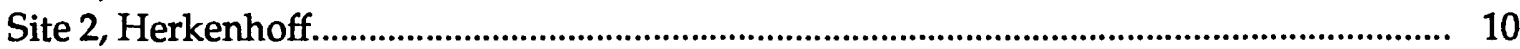

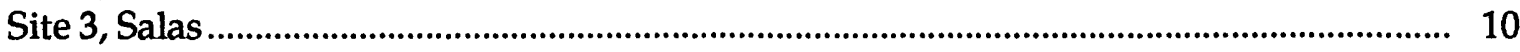

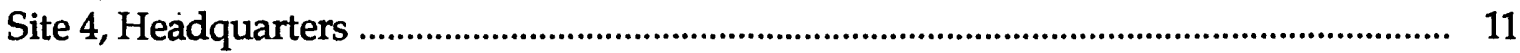

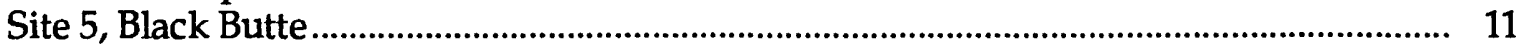

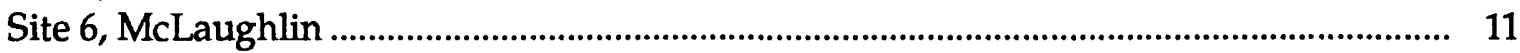

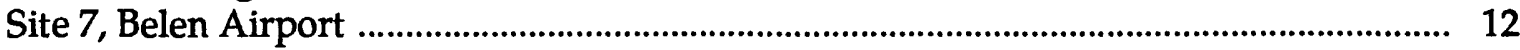

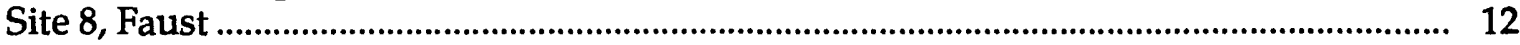

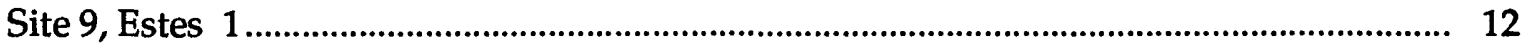

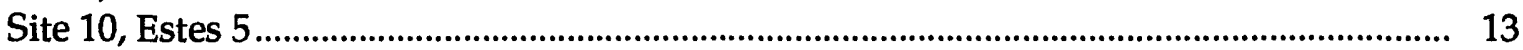

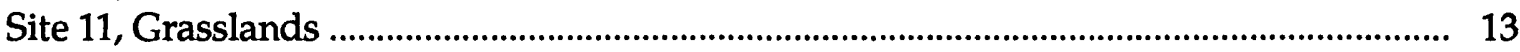

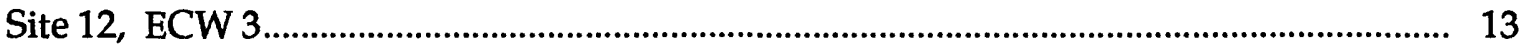

Site 13, Rio Puerco Trading Post ........................................................................... 14

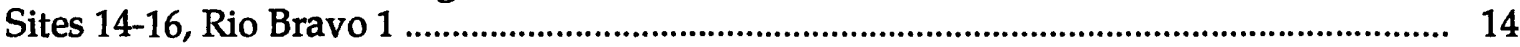

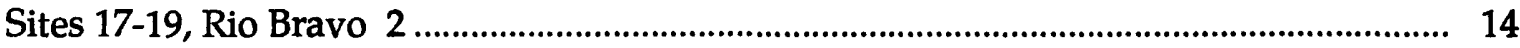

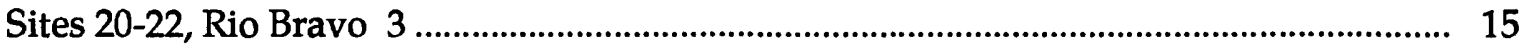

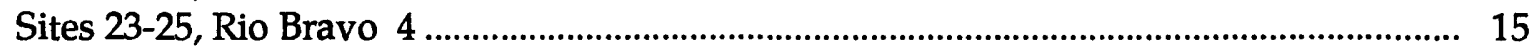

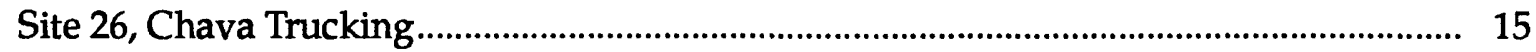

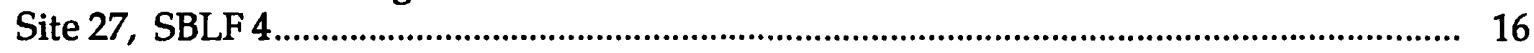

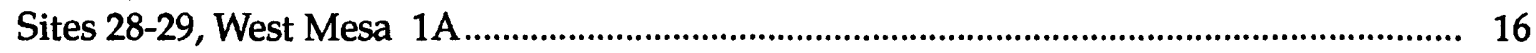

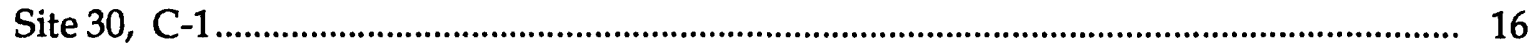

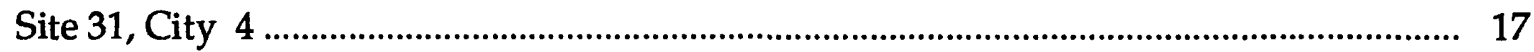




\section{FIGURES--Concluded}

3. Hydrographs showing water-level data from selected wells and piezometers in the Albuquerque Basin:

Site 32, Atrisco 6

Site 33, B.I.A.

Site 34, City 1

Site 35, Granite Hill

Site 36, Four Hills

Site 37, Eubank

Site 38, Home Oil

Site 39, Tijeras

Site 40, Sink Hole

Site 41, KAFB 5

Site 42, Dead Man's Curve .

Site 43, San Jose 9

Site 44 , San Jose 3

Site 45, Junction

Sites 46-48, West Mesa 2.

Site 49 , Nelson ...

Site 50, La Luz del Sol

Sites 51-53, Montaño 1

Sites 54-56, Montaño 2

Sites 57-59, Montaño 3

Sites 60-62, Montaño 4

Site 63, Shoemaker .

\section{Sites 64-66, West Mesa 3}

Site 67, City 3

Site 68, City 2

Site 69, Sandia R1

Site 70 , Vandermey

Site 71, Betania

Site 72, South Bosque .

Site 73, Middle Bosque

Site 74, North Bosque

Site 75, Sandia 2.

Site 76, San Miguel

Site 79, Tierra Mirage

\section{TABLE}

1. Well and piezometer data 


\section{CONVERSION FACTORS AND VERTICAL DATUM}

Multiply

foot

mile

acre
By

0.3048

1.609

4,047
To obtain

meter

kilometer

square meter

Sea level: In this report "sea level" refers to the National Geodetic Vertical Datum of 1929a geodetic datum derived from a general adjustment of the first-order level nets of the United States and Canada, formerly called Sea Level Datum of 1929. 


\title{
WATER-LEVEL DATA FOR THE \\ ALBUQUERQUE BASIN, NEW MEXICO, \\ OCTOBER 1, 1986, THROUGH SEPTEMBER 30, 1990
}

\author{
By Dale R. Rankin
}

\begin{abstract}
The Albuquerque Basin, located in central New Mexico, is about 100 miles long and 25 to 40 miles wide. The basin is defined as the extent of Cenozoic deposits that encompass the structural Rio Grande Rift within the basin. The drinking-water supply throughout the Albuquerque Basin is obtained solely from ground-water resources. The population of the basin grew from 419,000 in 1980 to 563,600 in 1990, a 34-percent increase, and resulted in increases in water demand and ground-water pumpage. Between April 1982 and September 1983, a network of wells was established to monitor changes in ground-water levels throughout the Albuquerque Basin. Water-level data are being collected at 79 wells and piezometers that presently (1994) comprise the network. This report summarizes ground-water-level data collected from October 1, 1986, through September 30, 1990, in the Albuquerque Basin.
\end{abstract}

\section{INTRODUCTION}

The Albuquerque Basin is located in central New Mexico and is about 100 miles long and 25 to 40 miles wide. The basin is defined as the extent of Cenozoic deposits that encompass the structural Rio Grande Rift within the basin (Thorn and others, 1993). The study area extends from Bernalillo south to San Acacia and from Tijeras Canyon west to near the intersection of Interstate 40 and the Bernalillo/Cibola County line (fig. 1). Parts of Sandoval, Bernalillo, Valencia, and Socorro Counties are located within the study area. The only perennial stream is the southward-flowing Rio Grande, which approximately bisects the basin.

The Albuquerque metropolitan area includes a population of 502,100 (U.S. Department of Commerce, 1991). Although the majority of people are concentrated within the Albuquerque city limits, the basinwide population increased from 419,000 in 1980 to 563,600 in 1990, an increase of 34 percent. The demand for ground water has likewise increased since because the drinking-water supply throughout the Albuquerque Basin is obtained solely from ground-water resources (Kues, 1987).

This report provides water-level and other data for selected wells and piezometers in the Albuquerque Basin, central New Mexico (Wilkins, 1986; Anderholm and Bullard, 1987; and Kues, 1987). Water levels of 79 wells and piezometers measured by U.S. Geological Survey personnel from October 1, 1986, through September 30, 1990, are included. 


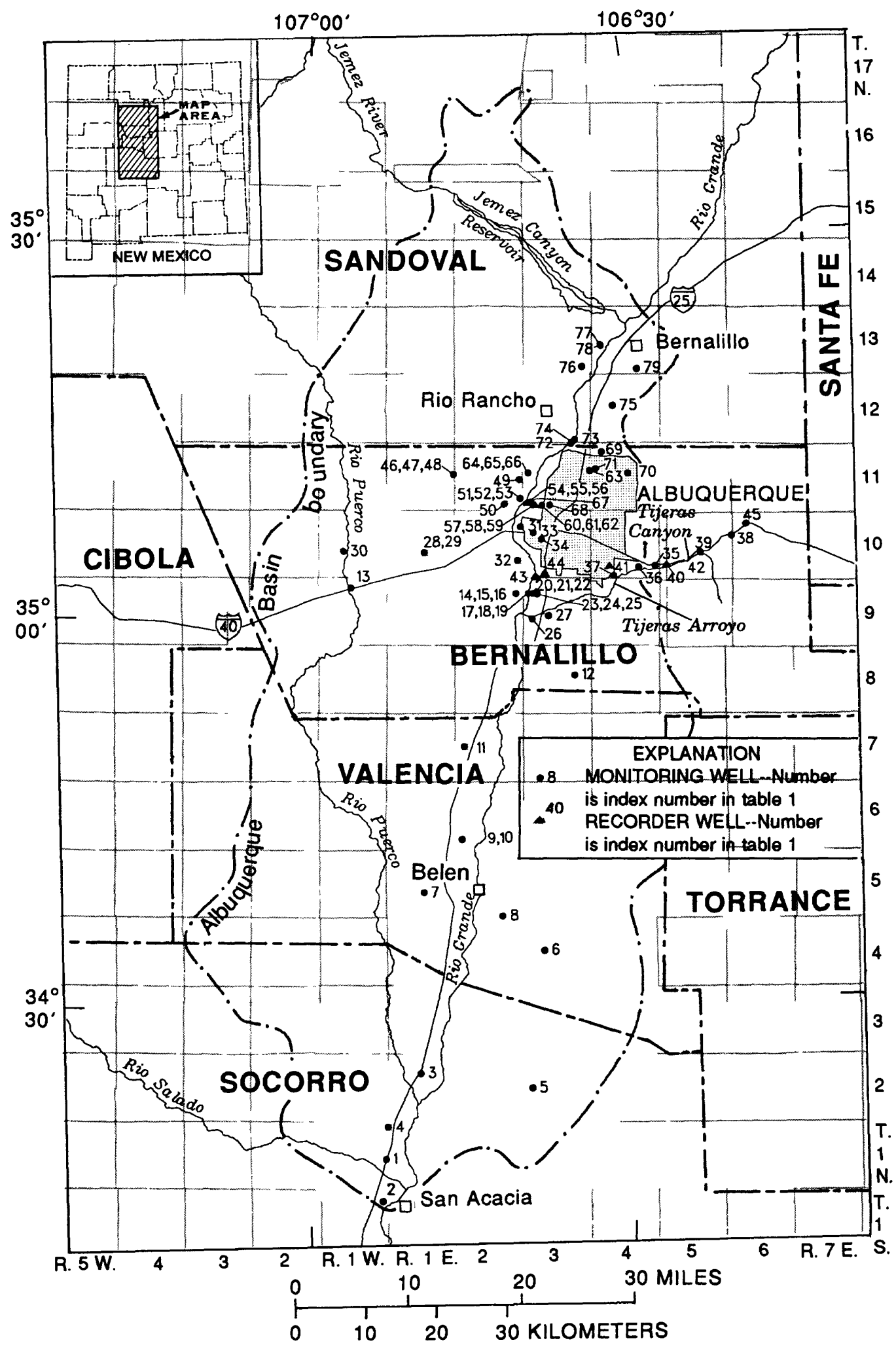

Figure 1.--Location of study area. 


\section{Well-Numbering System}

The system of numbering wells in New Mexico is based on the common subdivision of public lands into sections (fig. 2). The well number, in addition to designating the well, locates its position to the nearest 10-acre tract in the land network. This number is divided into four segments. The first segment denotes the township north of the New Mexico base line, the second denotes the range east of the New Mexico principal meridian, and the third denotes the section. The fourth segment of the number, which consists of three digits, denotes the 160-, 40-, and 10acre tracts, respectively, in which the well is situated. For this purpose, the section is divided into four quarters, numbered 1,2,3, and 4, in the normal reading order, for the northwest, northeast, southwest, and southeast quarters. The first digit of the fourth segment gives the quarter section, which is a tract of 160 acres. Similarly, the quarter section is divided into four 40 -acre tracts numbered in the same manner, and the second digit denotes the 40-acre tract. Finally, the 40-acre tract is divided into four 10-acre tracts, and the third digit denotes the 10-acre tract. For example, well 10N.03E.32.412 is in the NE 1/4 of the NW 1/4 of the SE 1/4 of section 32, T. 10 N., R. 3 E. (fig. 2). Letters A, B, C, etc. are added to the last segment of the well number to designate the second, third, fourth, and succeeding wells in the same 10-acre tract.

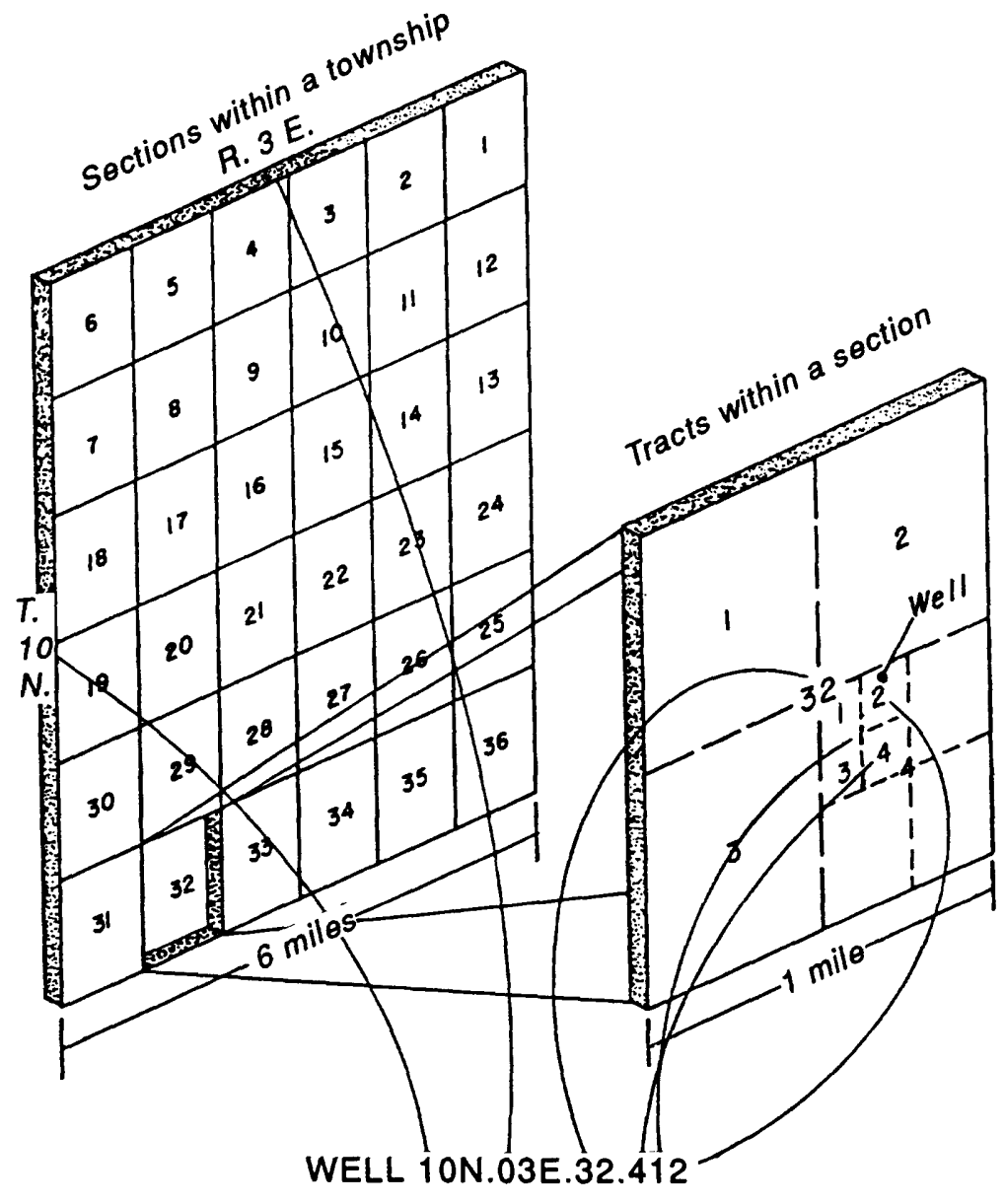

Figure 2.--System of numbering wells in New Mexico. 


\section{Methods}

The water-level data were collected by U.S. Geological Survey personnel. Water levels at site 11 are measured annually; at sites $1-10$, semiannually; at sites 28,29 , and $46-48$, quarterly; and at sites 12-27, 30-40, 45, 49-53, and 60-79, monthly. Electric and steel tapes are used to collect data from sites measured annually, semiannually, quarterly, and monthly. Water levels at sites 41-44 are monitored with Fischer-Porter ${ }^{1}$ analog-to-digital recorders. Water levels at sites 54-59 are monitored with Campbell CR-21 ${ }^{1}$ data loggers. The recorders and loggers record water levels hourly.

\section{WATER-LEVEL AND OTHER DATA}

Well and piezometer data are listed in table 1 . The data in table 1 include site number, site identifier, local identifier, owner, other identifier, total depth, and screened interval of wells and piezometers in the network. Hydrographs of water-level data for the 5-year record are shown in figure 3. The well name on each hydrograph shown in figure 3 refers to the "other identifier" column in table 1. In cases where "other identifier" is not available, the well name refers to the well owner. The data presented in the hydrographs include the depth to water, in feet below land surface, and the hydraulic head, in feet above sea level. Hydraulic head refers to the altitude of the water level. In some cases the recorded data are incomplete because of recorder malfunction; in other cases, the recorder was temporarily removed for sampling. The data shown on some hydrographs (for example, site 37) appear to be incomplete; these sites were added to the network at a later date.

\section{REFERENCES CITED}

Anderholm, S.K., and Bullard, T.F., 1987, Description of piezometer nests and water levels in the Rio Grande Valley near Albuquerque, Bernalillo County, New Mexico: U.S. Geological Survey Open-File Report 87-122, $51 \mathrm{p}$.

Kues, G.E., 1987, Ground-water-level data for the Albuquerque-Belen Basin, New Mexico, through water year 1985: U.S. Geological Survey Open-File Report 87-116, 51 p.

Thorn, C.R., McAda, D.P., and Kernodle, J.M., 1993, Geohydrologic framework and hydrologic conditions in the Albuquerque Basin, central New Mexico: U.S. Geological Survey WaterResources Investigations Report 93-4149, $106 \mathrm{p}$.

U.S. Bureau of the Census, 1980: Master area reference file for 1980 census. 1991: Master area reference file for 1991 census.

U.S. Department of Commerce, 1991, 1990 census of population and housing; Summary population and housing characteristics, New Mexico: 1990 CPH-1-33, variously paged.

Wilkins, D.W., 1986, Characteristics and properties of the basin-fill aquifer determined from three test wells west of Albuquerque, Bernalillo County, New Mexico: U.S. Geological Survey Water-Resources Investigations Report 86-4187, 78 p.

${ }^{1}$ Use of brand names in this report is for identification purposes only and does not constitute endorsement by the U.S. Geological Survey. 


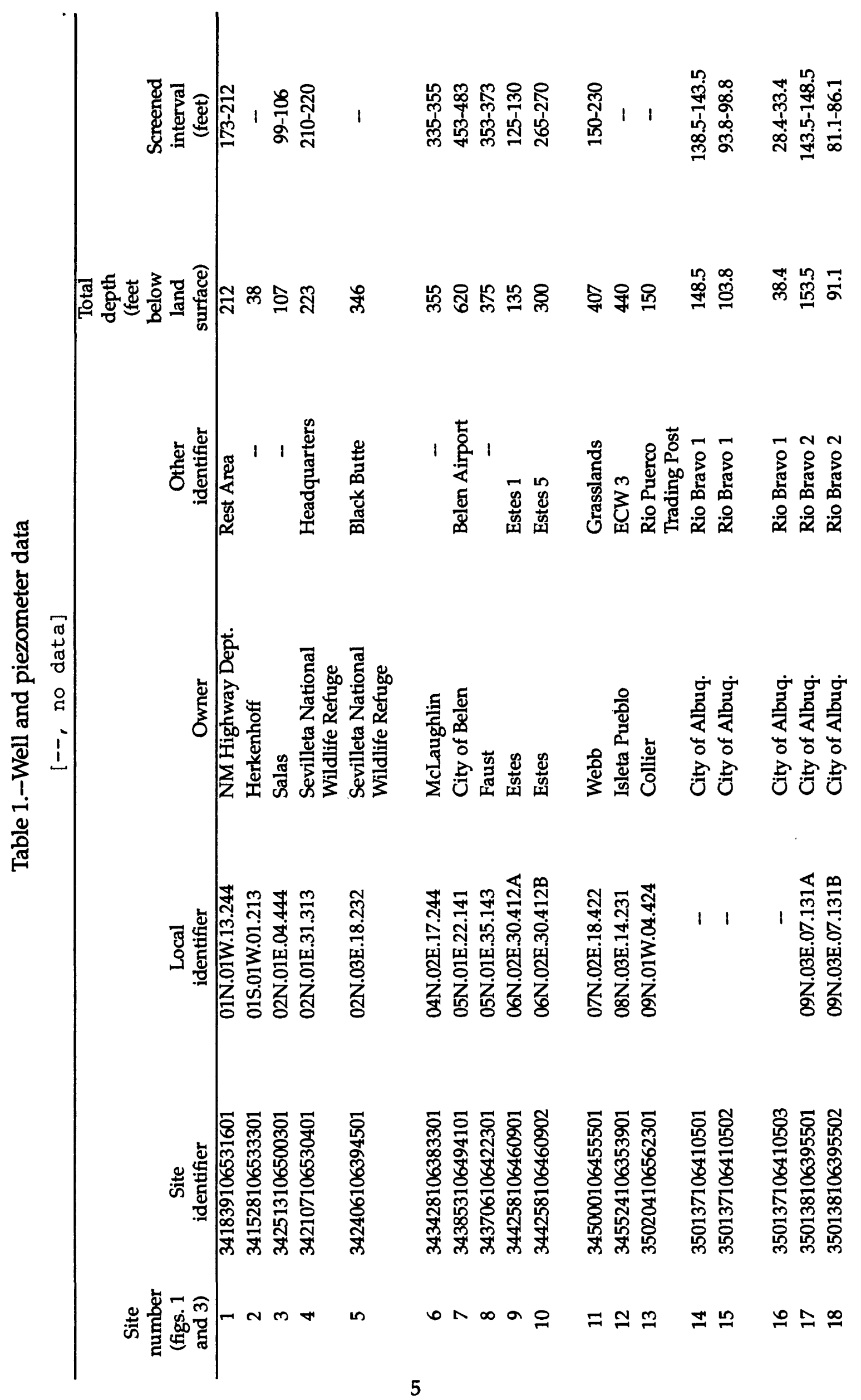




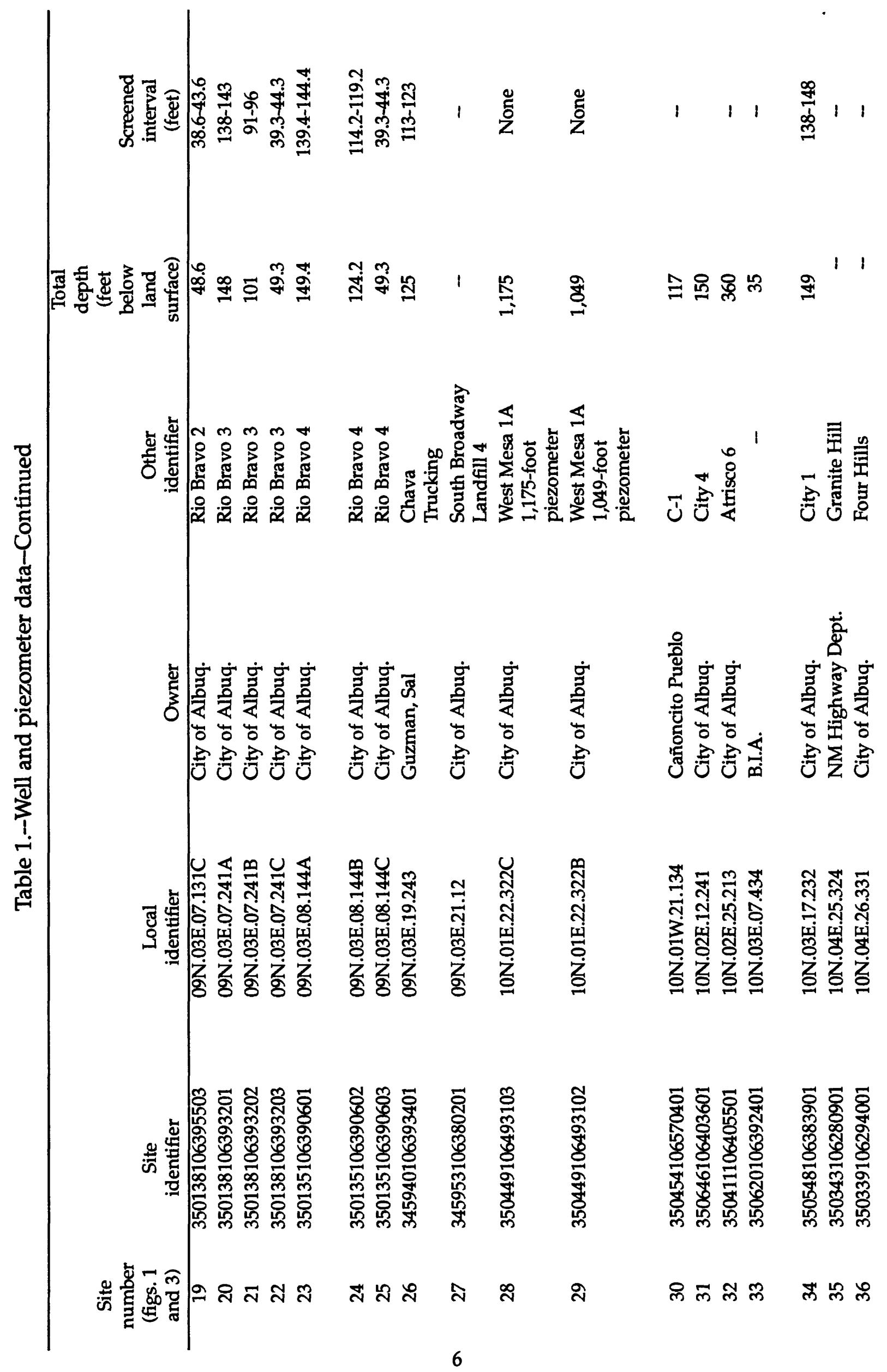




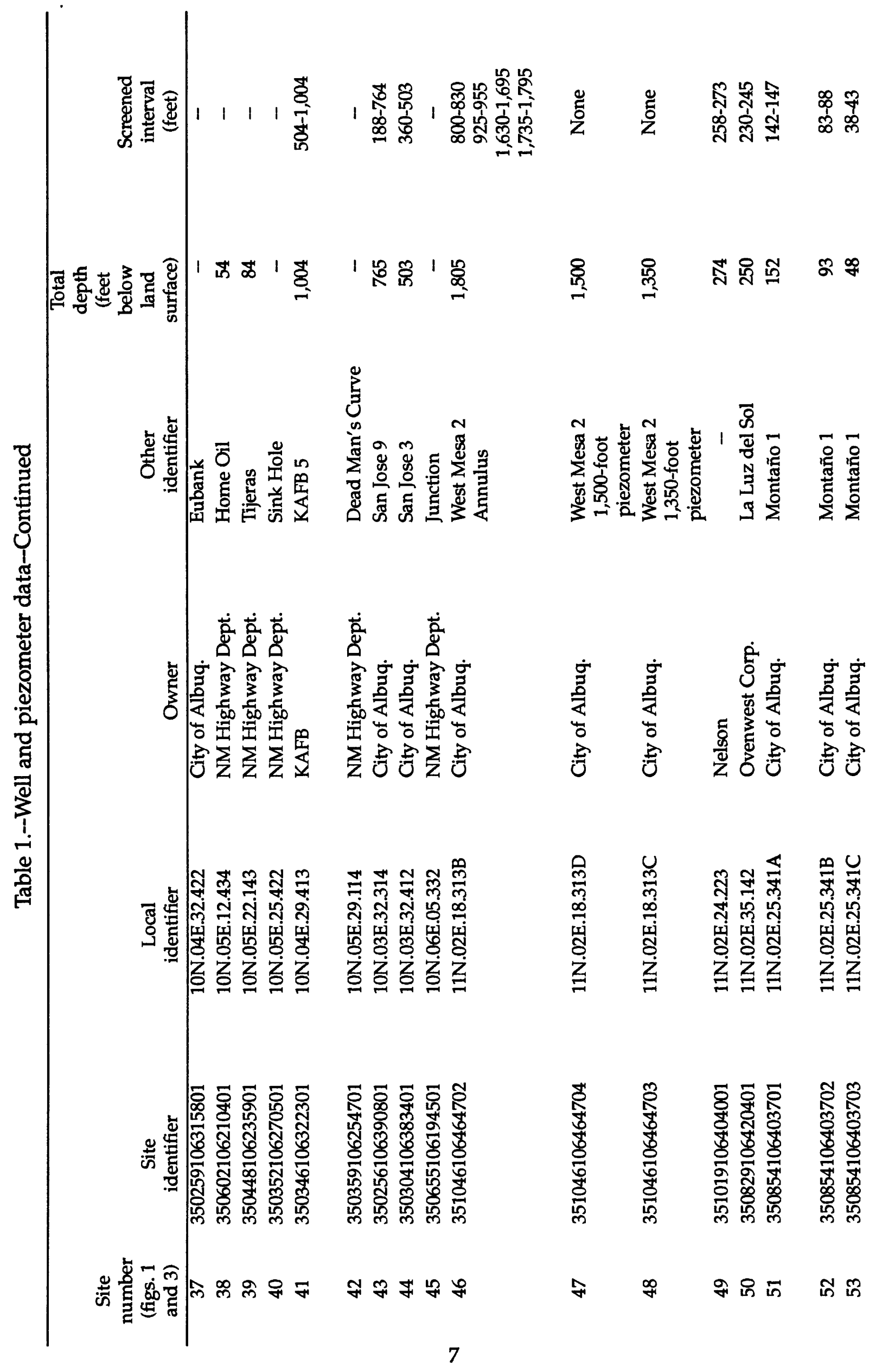




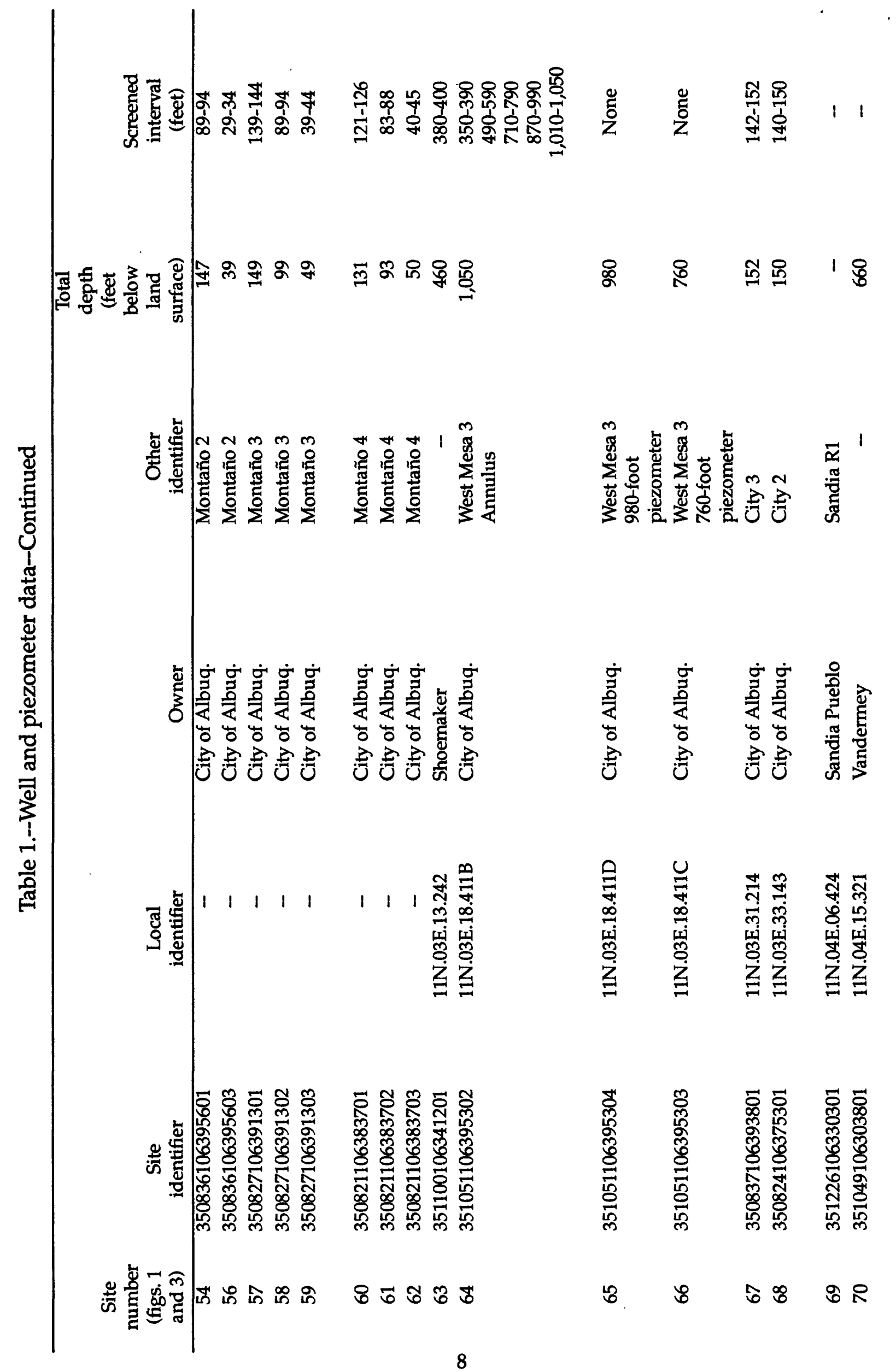




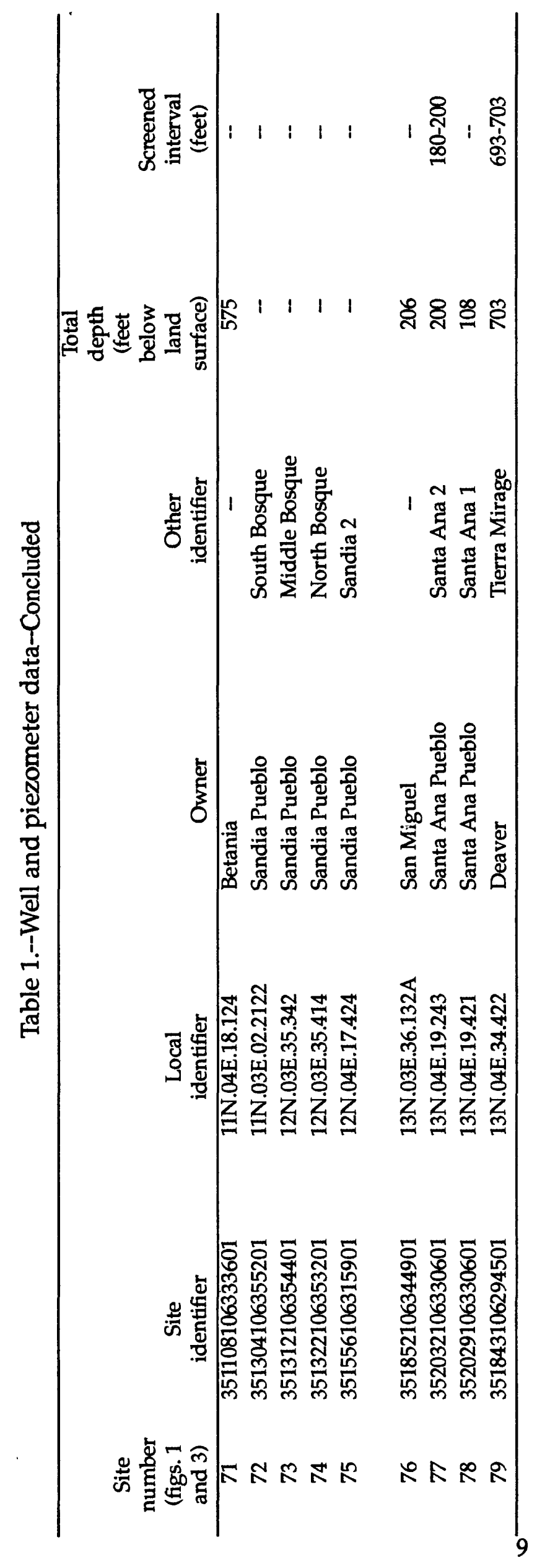




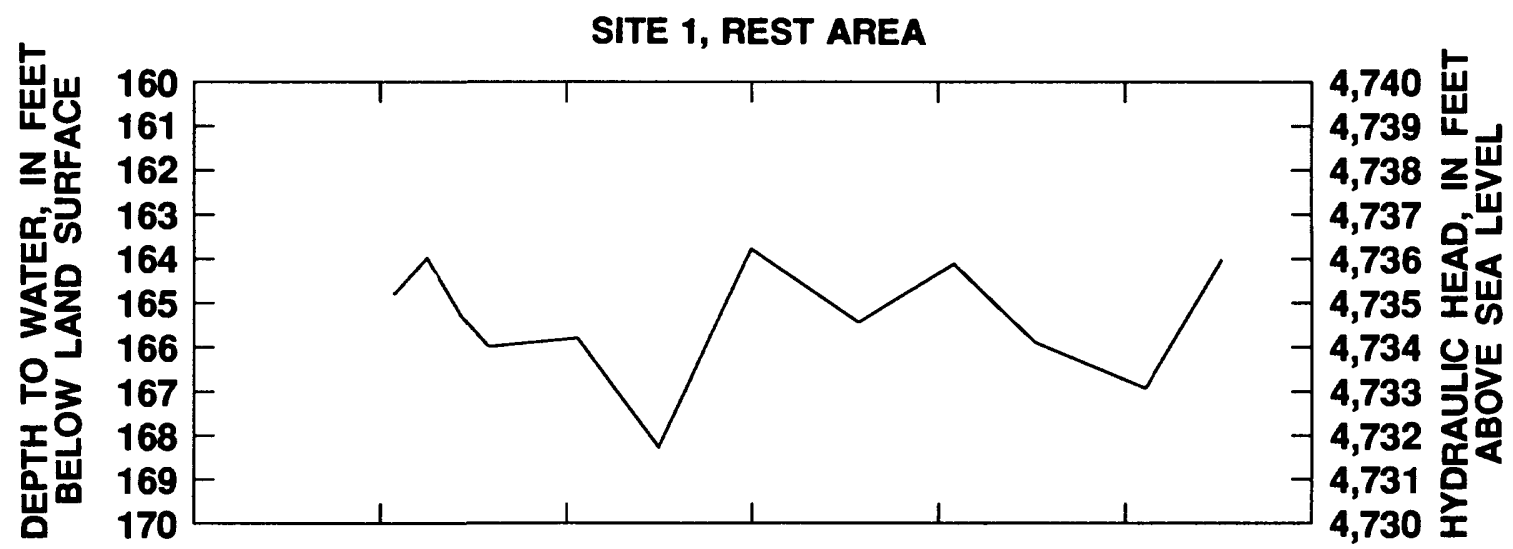

SITE 2, HERKENHOFF
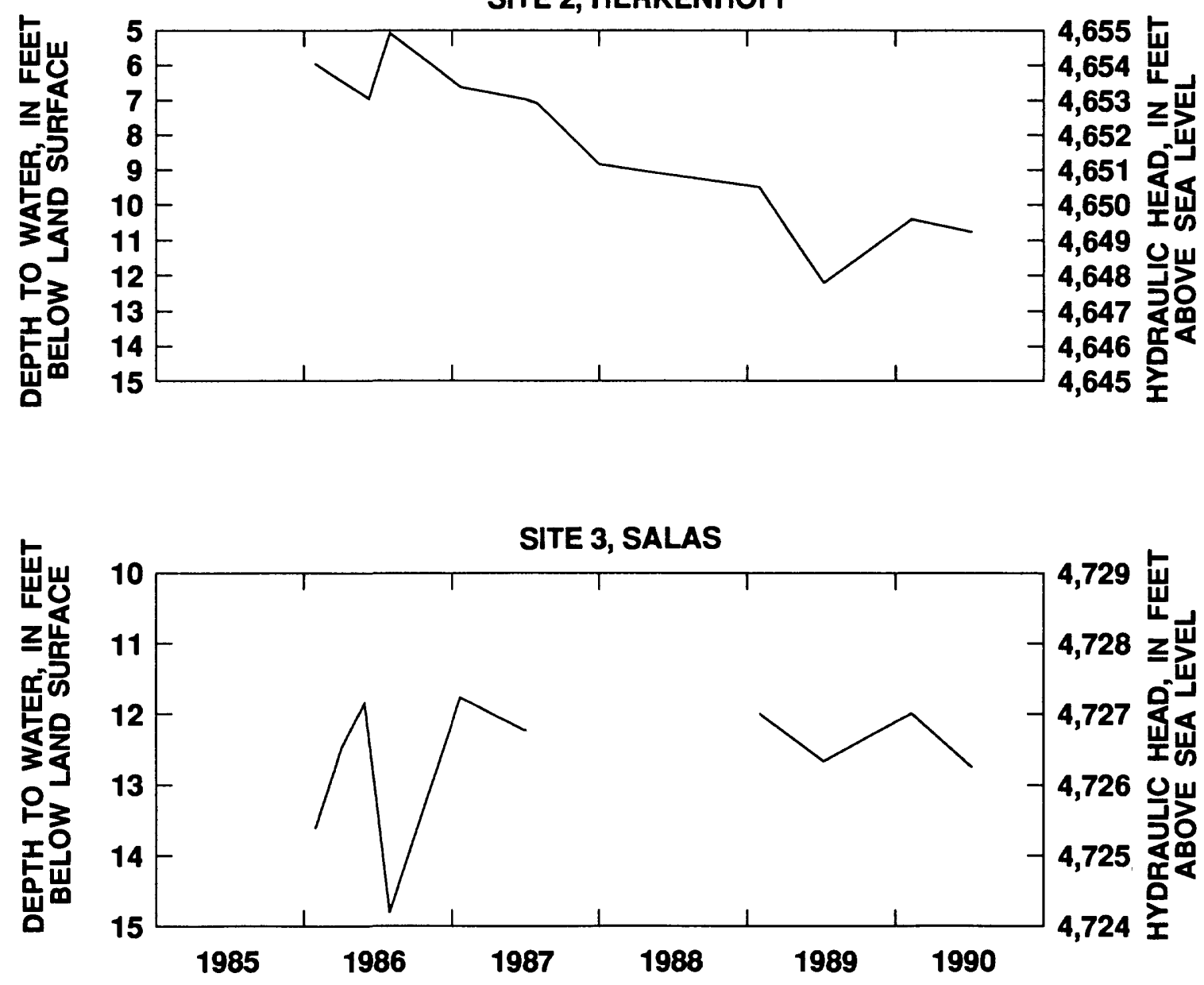

Figure 3.--Water-level data from selected wells and piezometers in the Albuquerque Basin (site location shown in figure 1 ). 
SITE 4, HEADQUARTERS
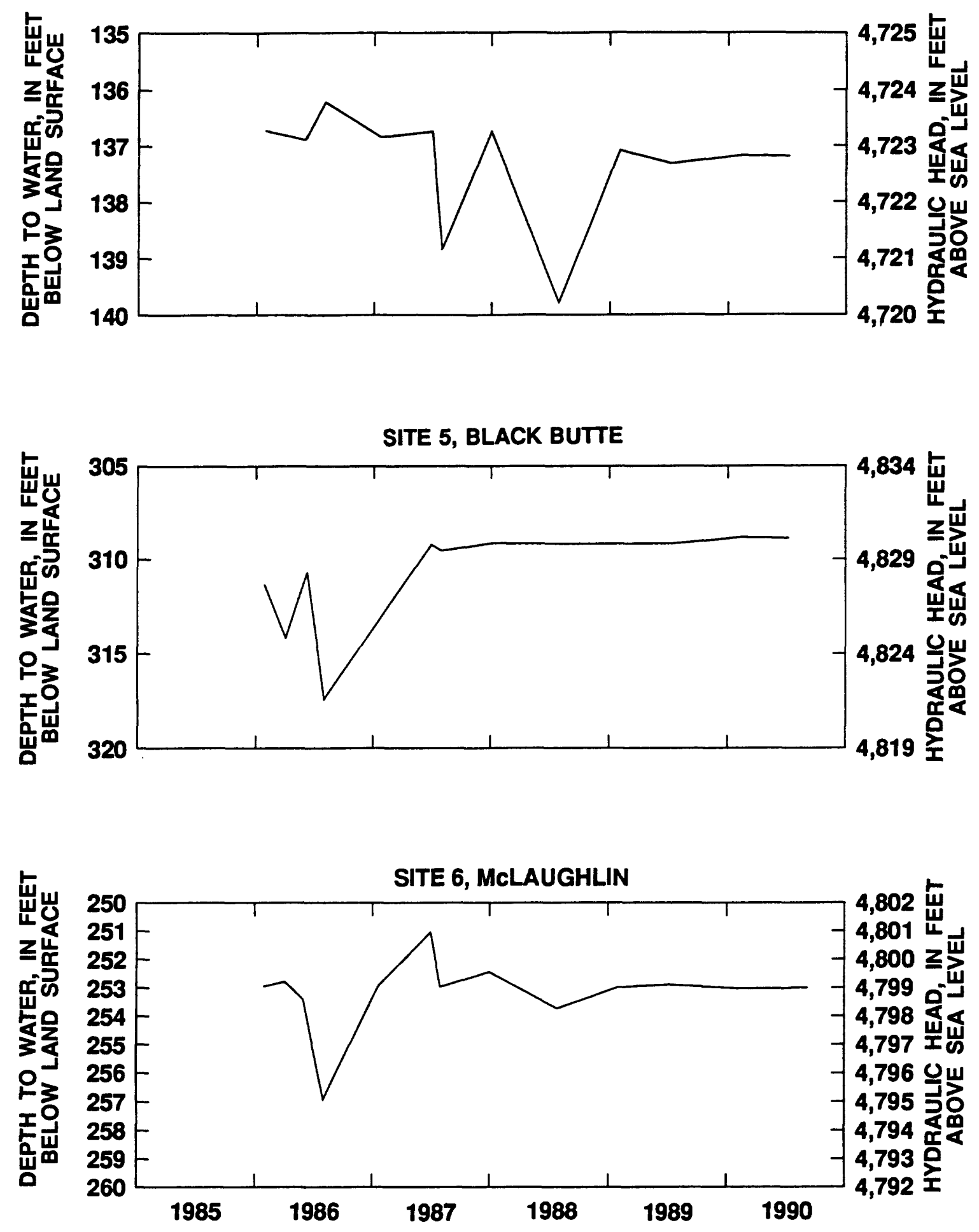

Figure 3.--Water-level data from selected wells arid piezometers in the Albuquerque Basin (site location shown in figure 1) - Continued. 

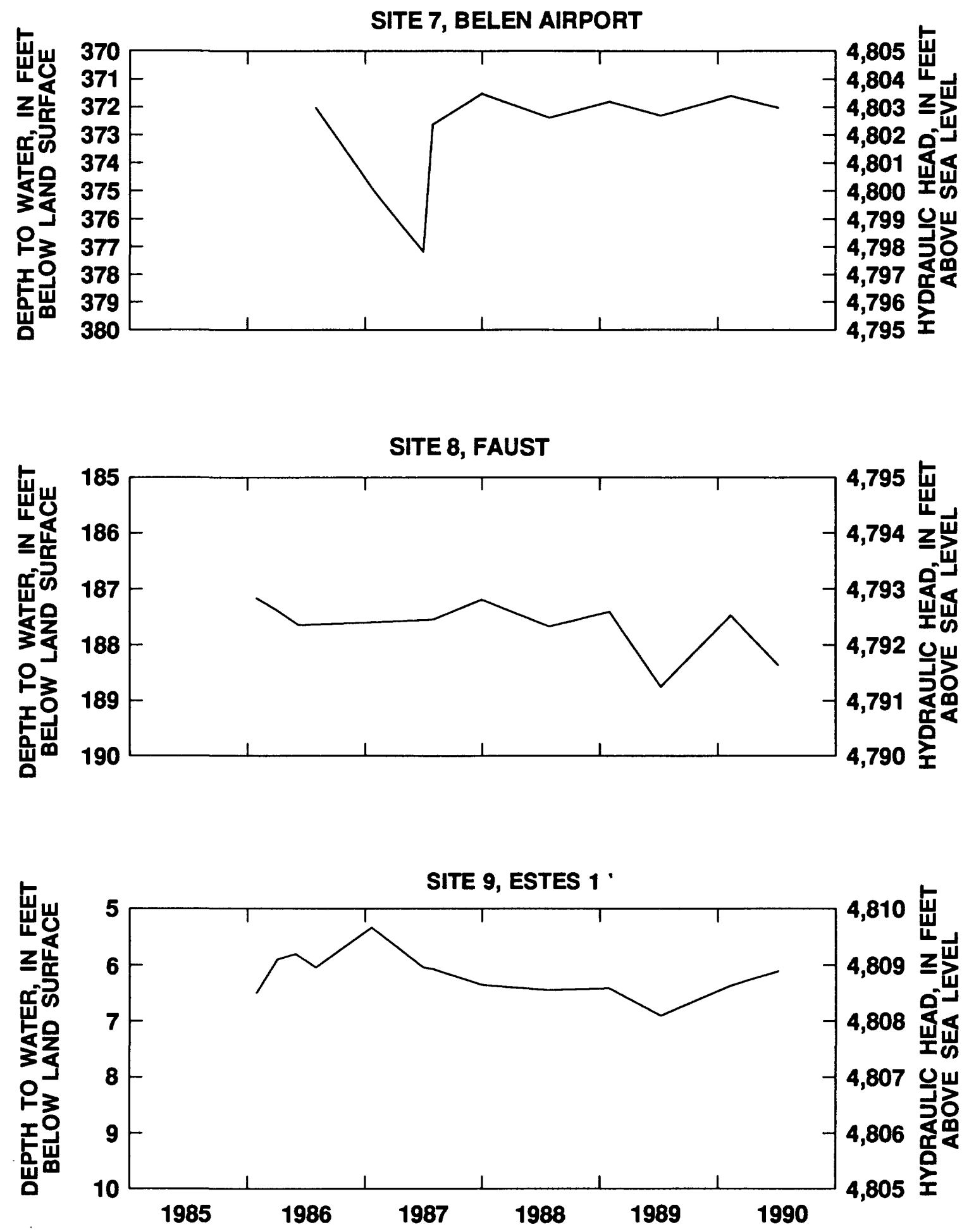

Figure 3.--Water-level data from selected wells and piezometers in the Albuquerque Basin (site location shown in figure 1 ) - Continued. 

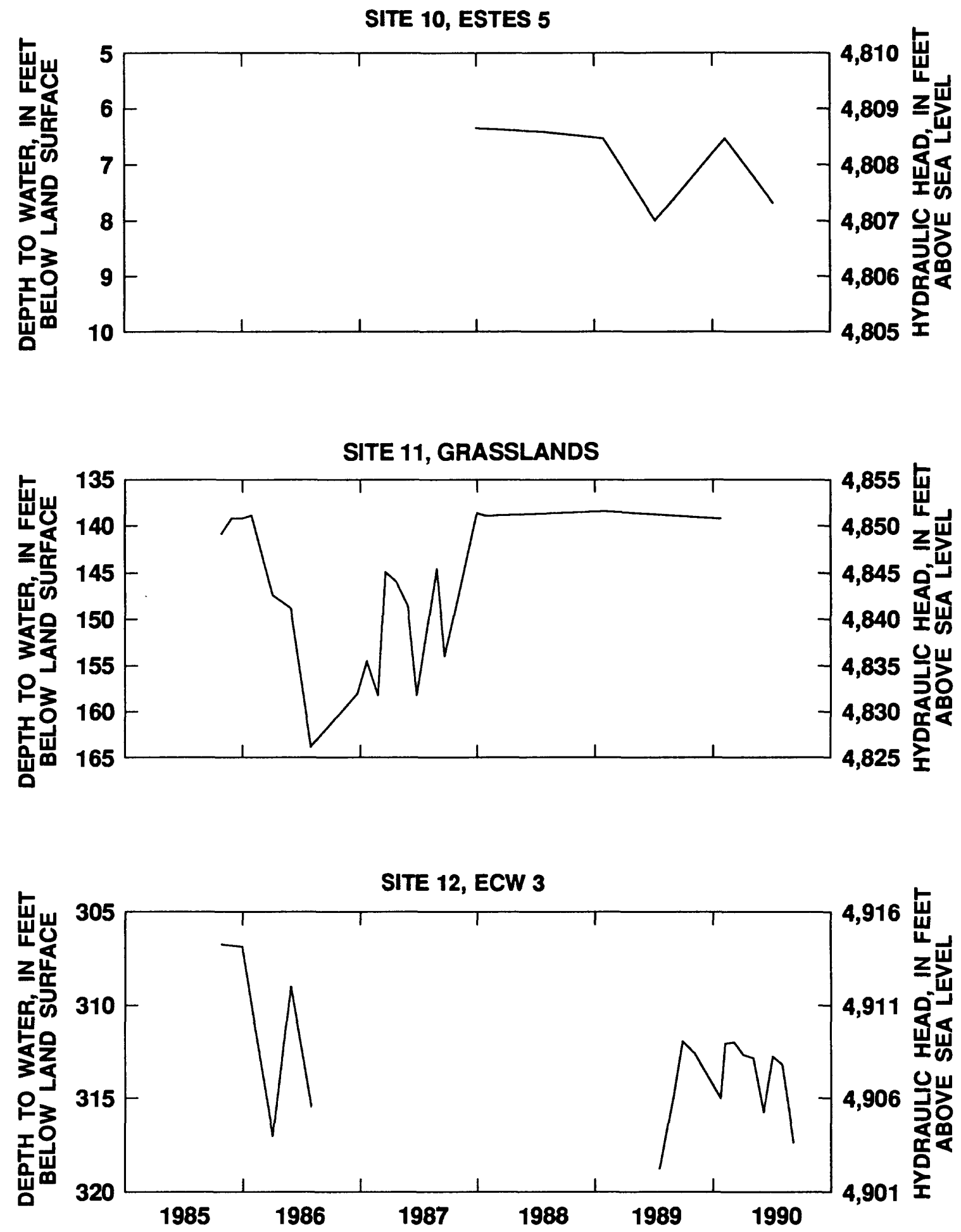

Figure 3.--Water-level data from selected wells and piezometers in the Albuquerque Basin (site location shown in figure 1 ) - Continued. 


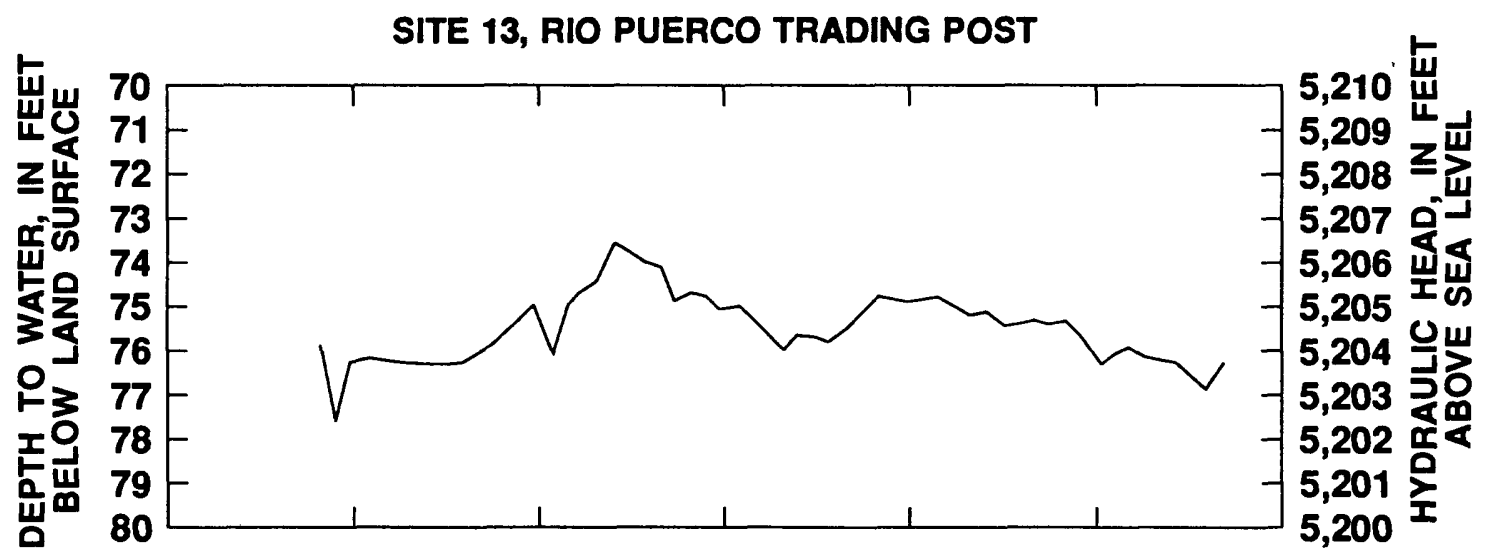

SITES 14-16, RIO BRAVO 1
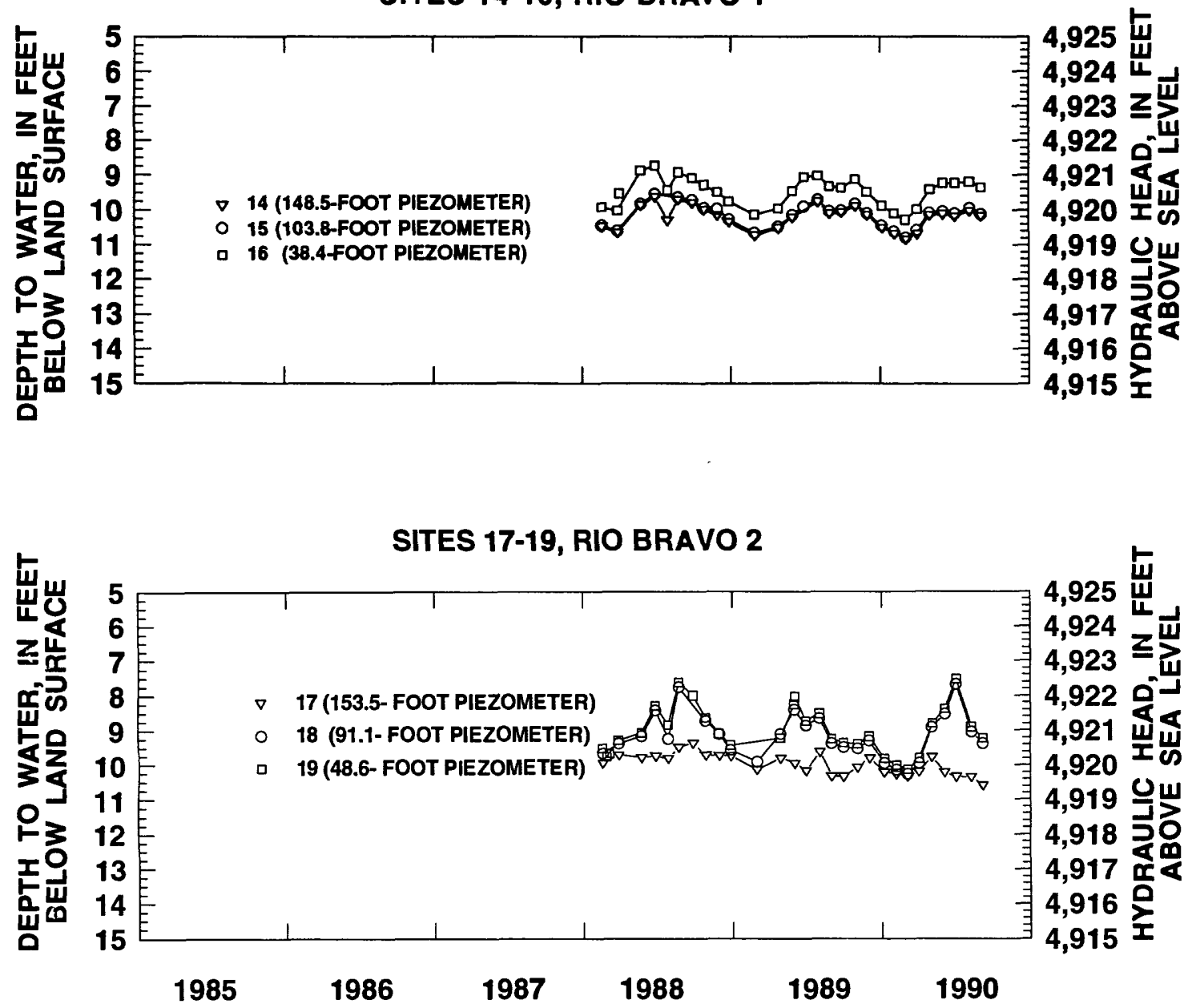

Figure 3.--Water-level data from selected wells and piezometers in the Albuquerque Basin (site location shown in figure 1) - Continued. 
SITES 20-22, RIO BRAVO 3

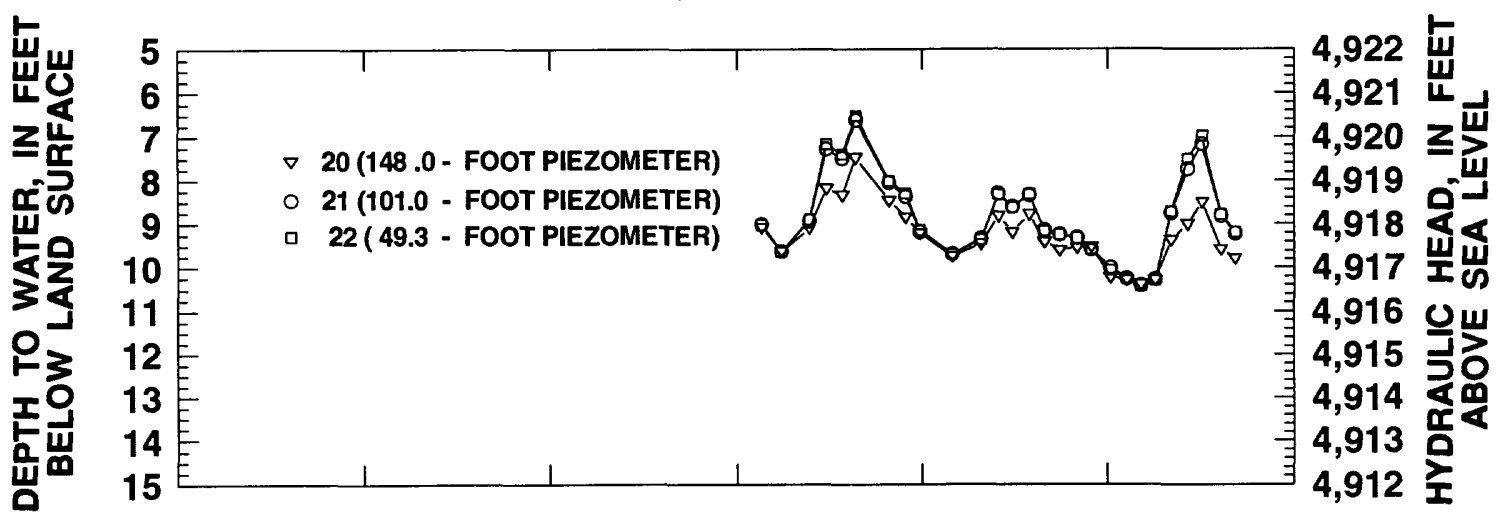

SITES 23-25, RIO BRAVO 4
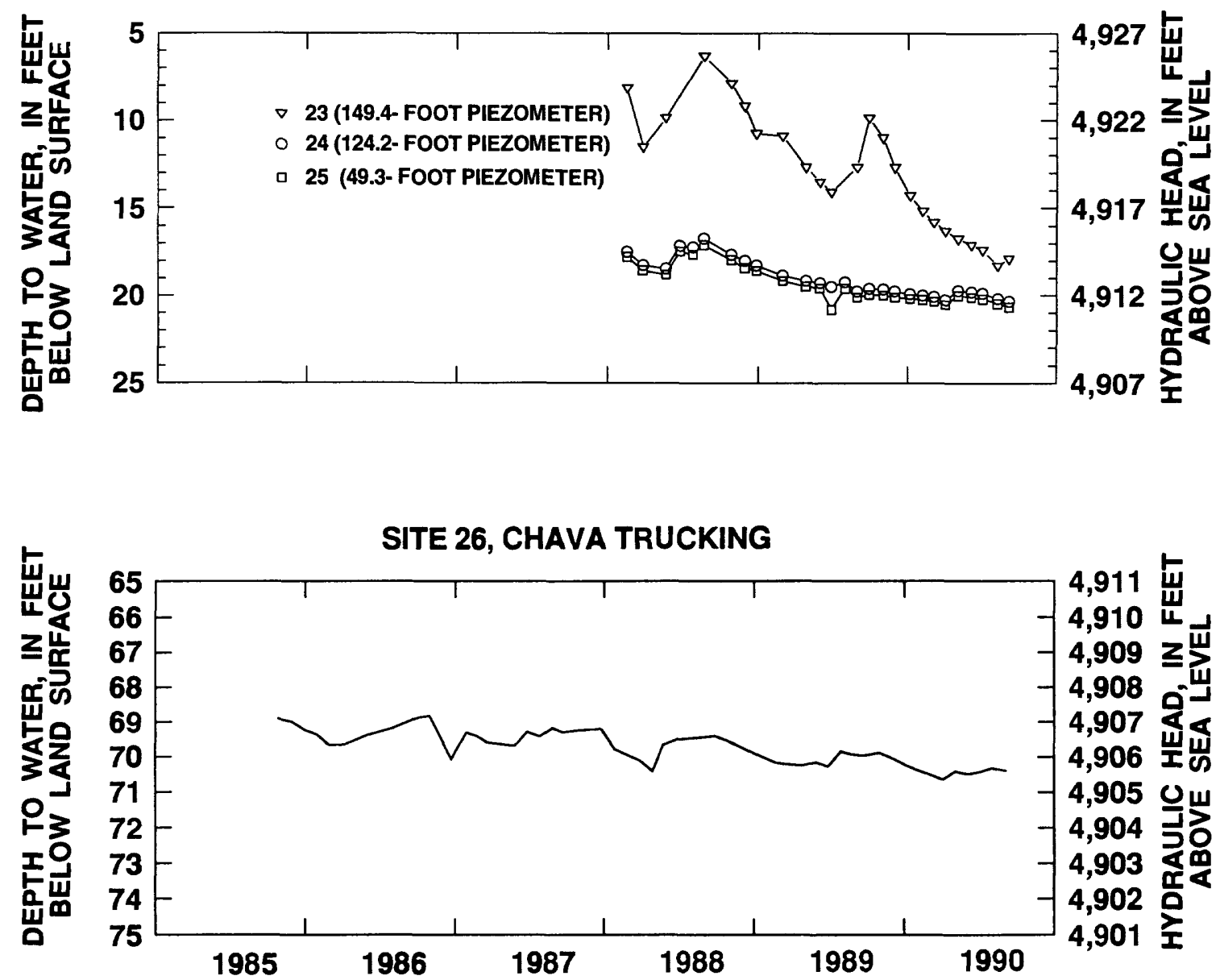

Figure 3.--Water-level data from selected wells and piezometers in the Albuquerque Basin (site location shown in figure 1) - Continued. 

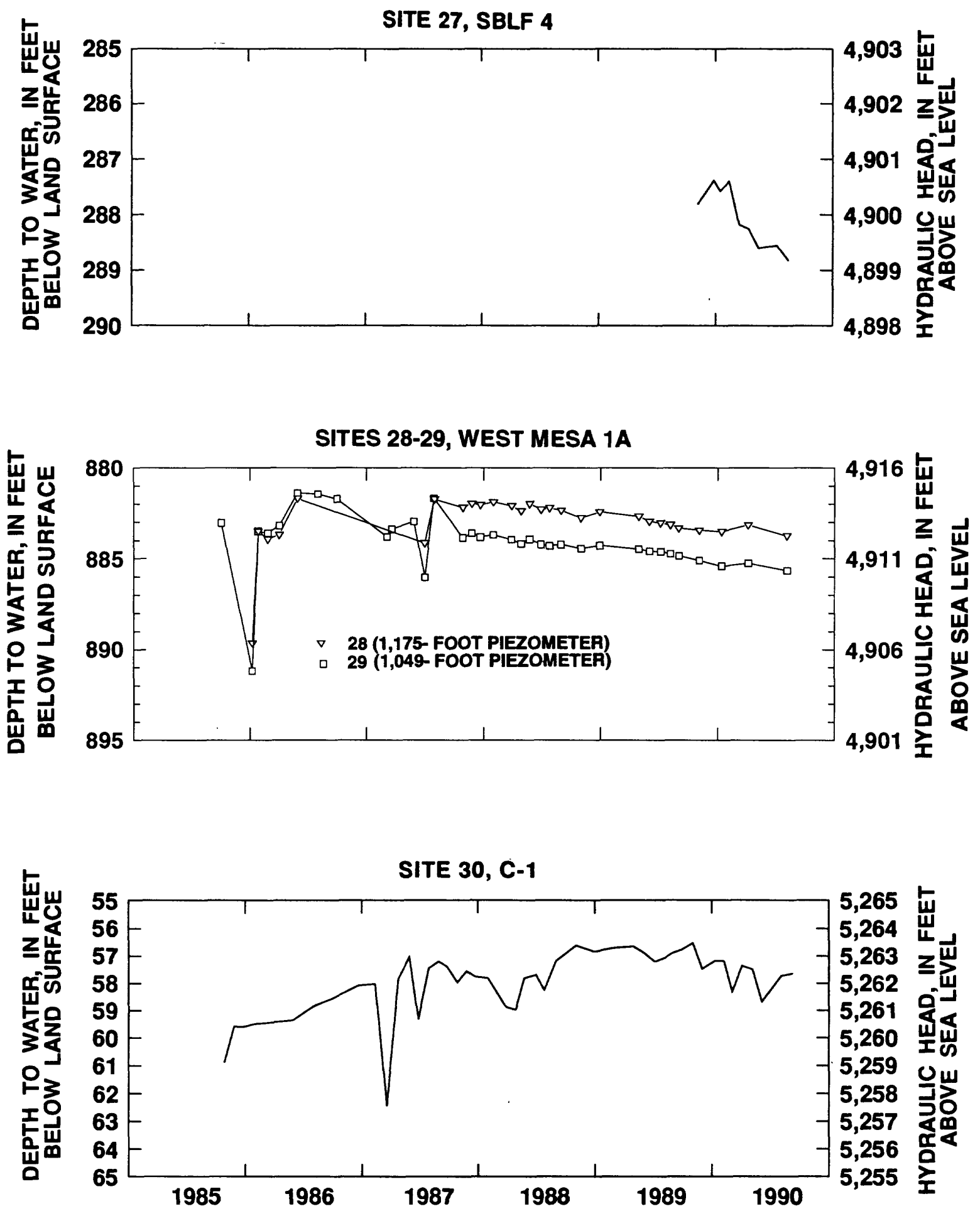

Figure 3.--Water-level data from selected wells and piezometers in the Albuquerque Basin (site location shown in figure 1 ) - Continued. 


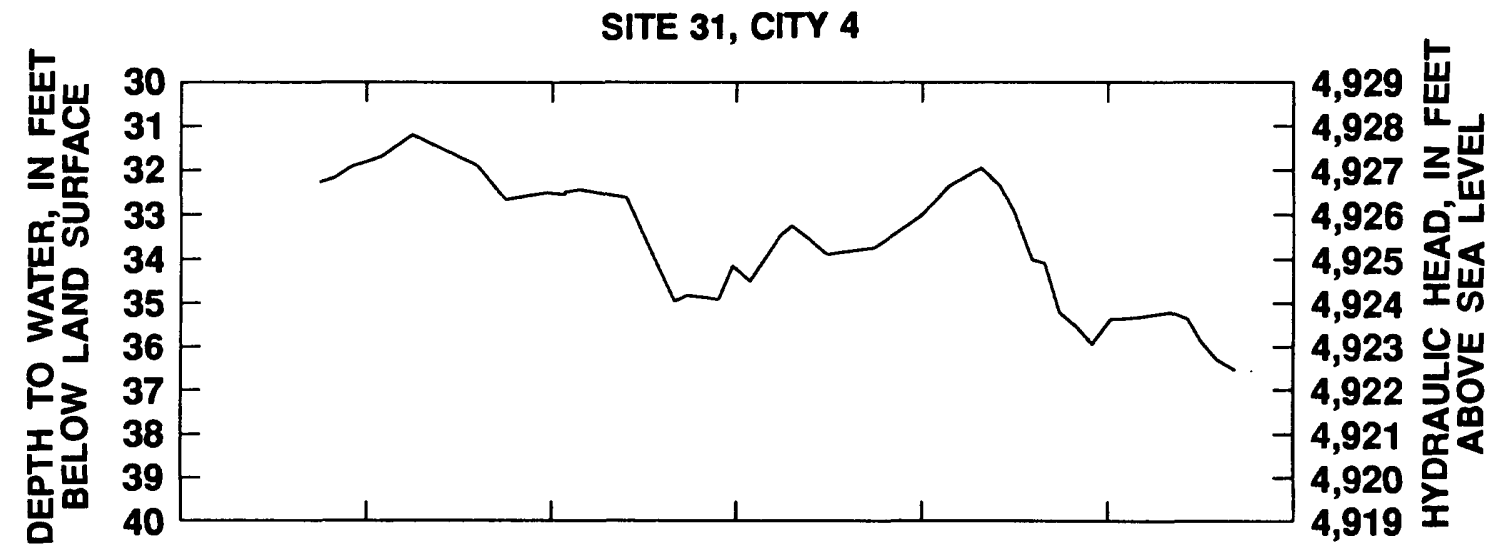

SITE 32, ATRISCO 6

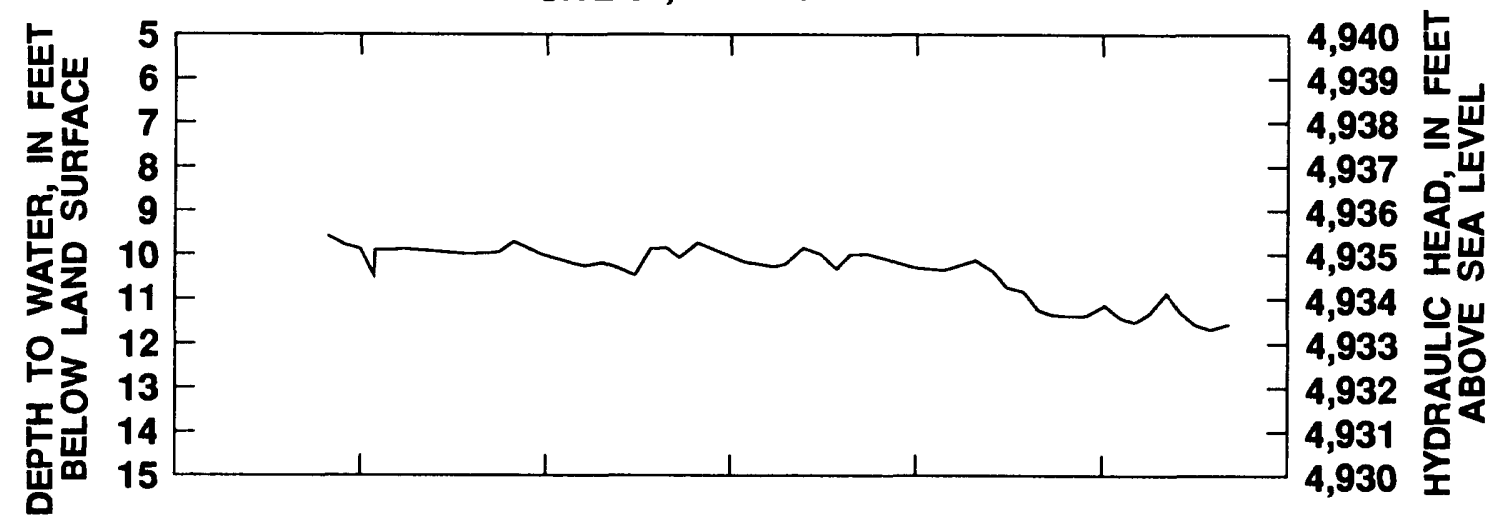

SITE 33, B.I.A.

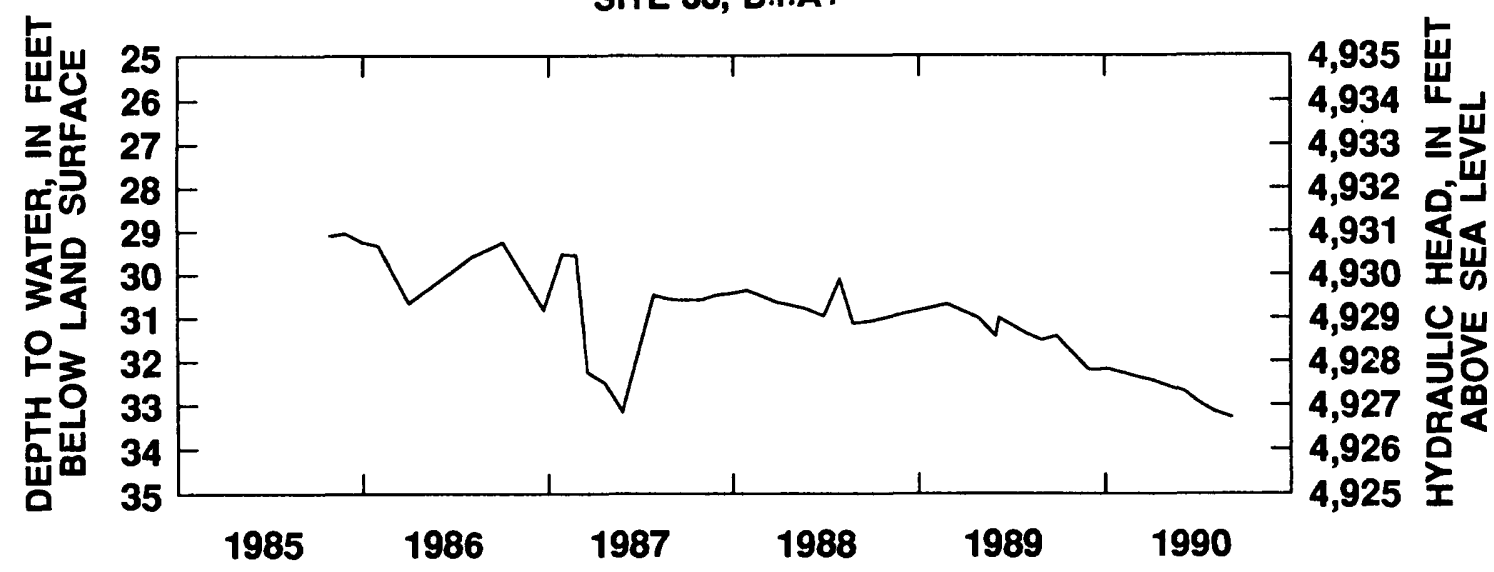

Figure 3.--Water-level data from selected wells and piezometers in the Albuquerque Basin (site location shown in figure 1 ) - Continued. 


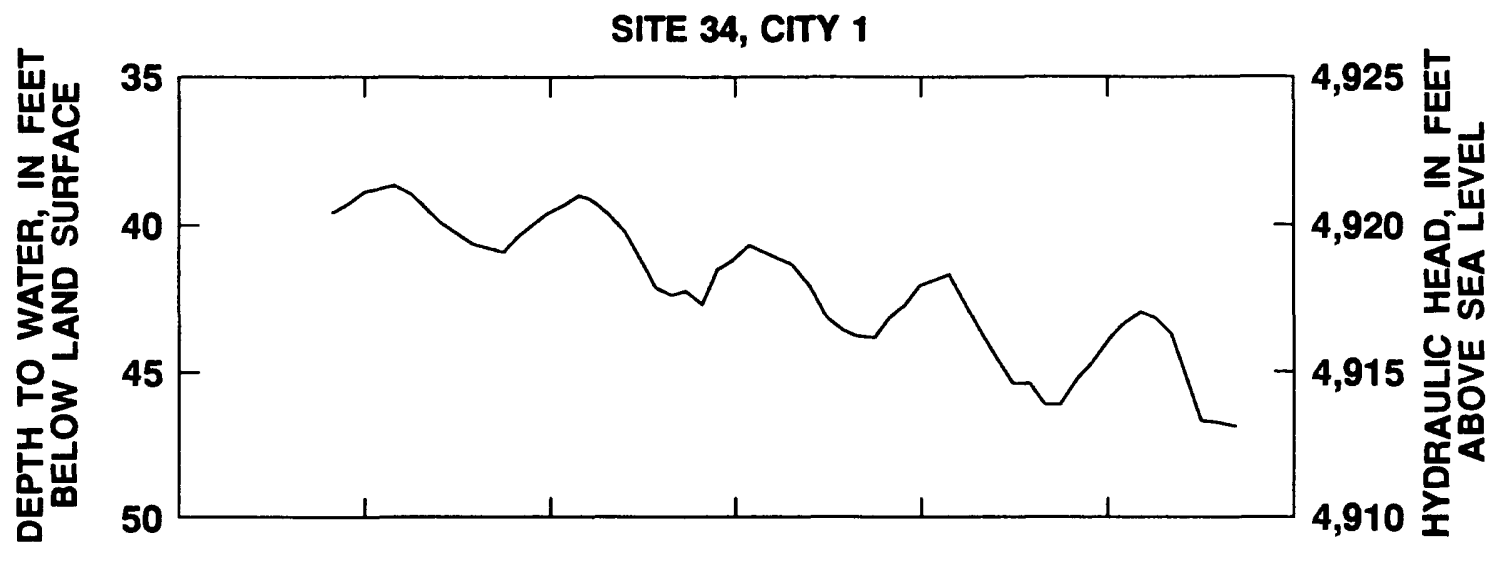

SITE 35, GRANITE HILL
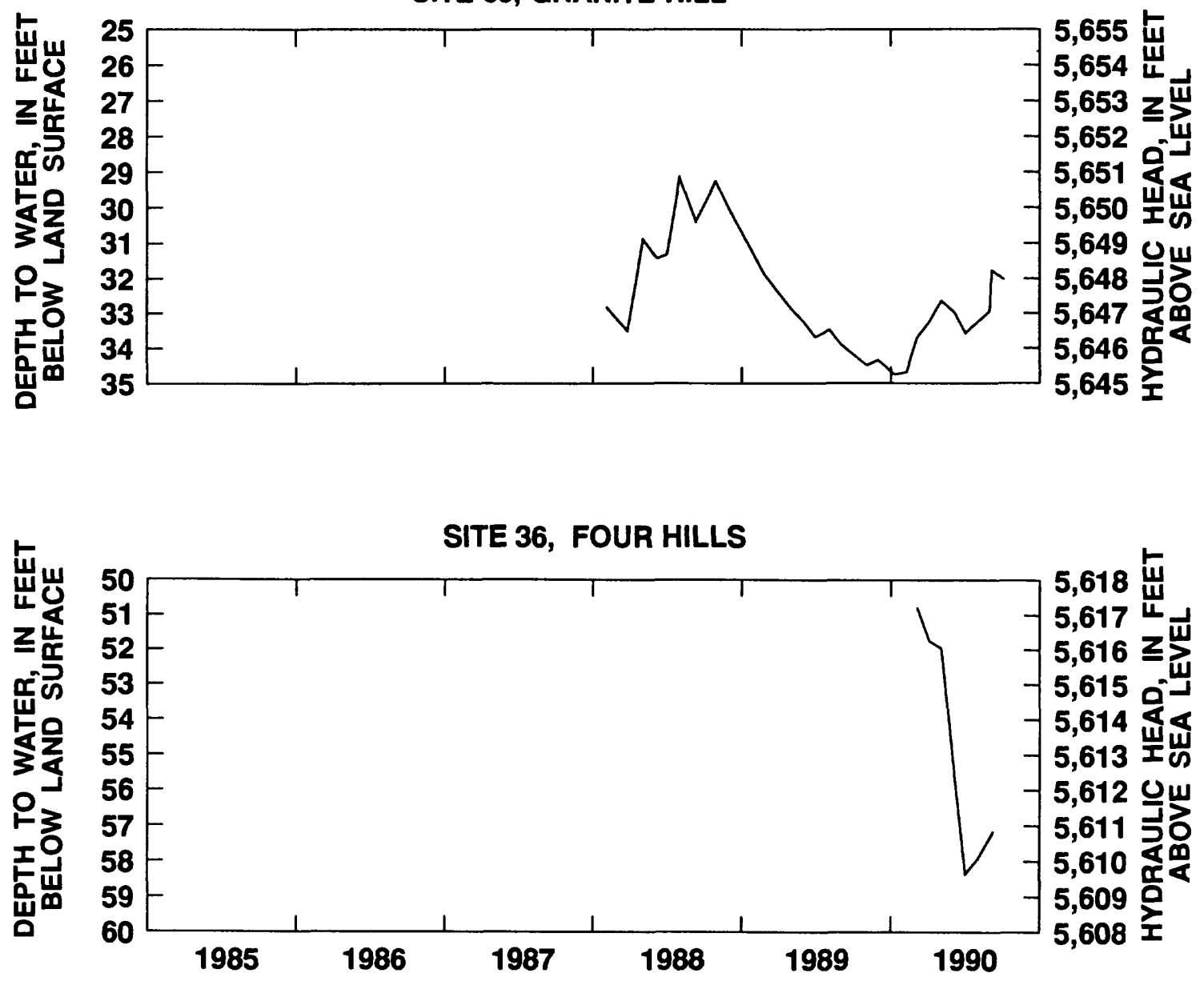

Figure 3.--Water-level data from selected wells and piezometers in the Albuquerque Basin (site location shown in figure 1 ) - Continued. 
SITE 37, EUBANK

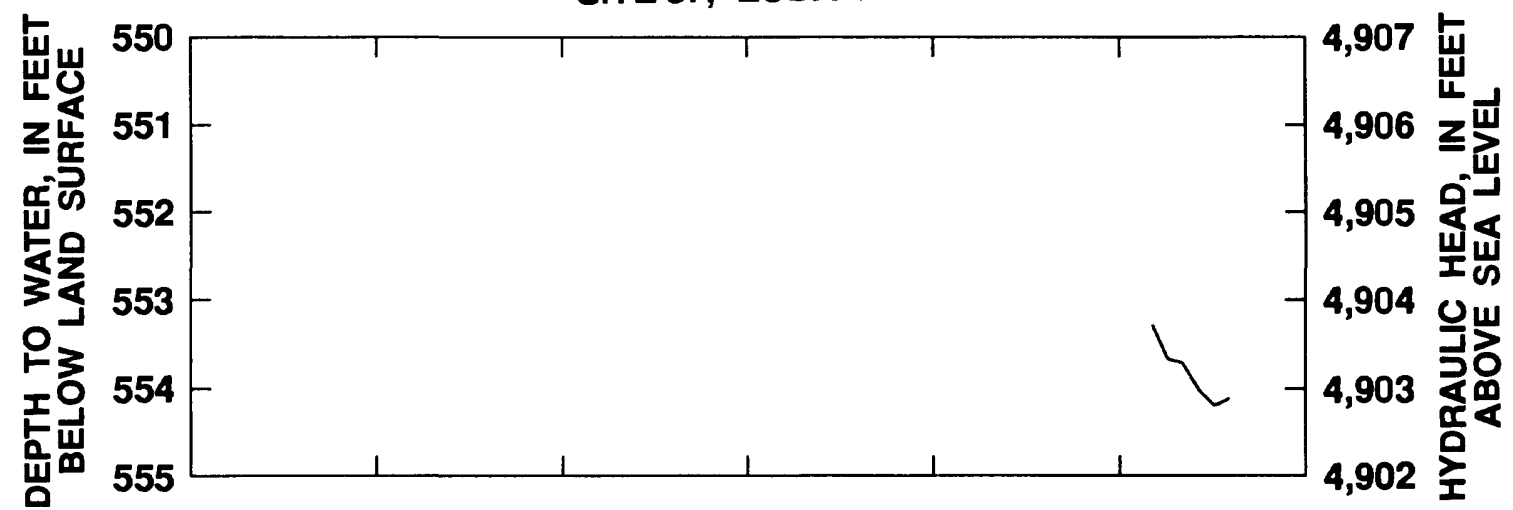

SITE 38, HOME OIL

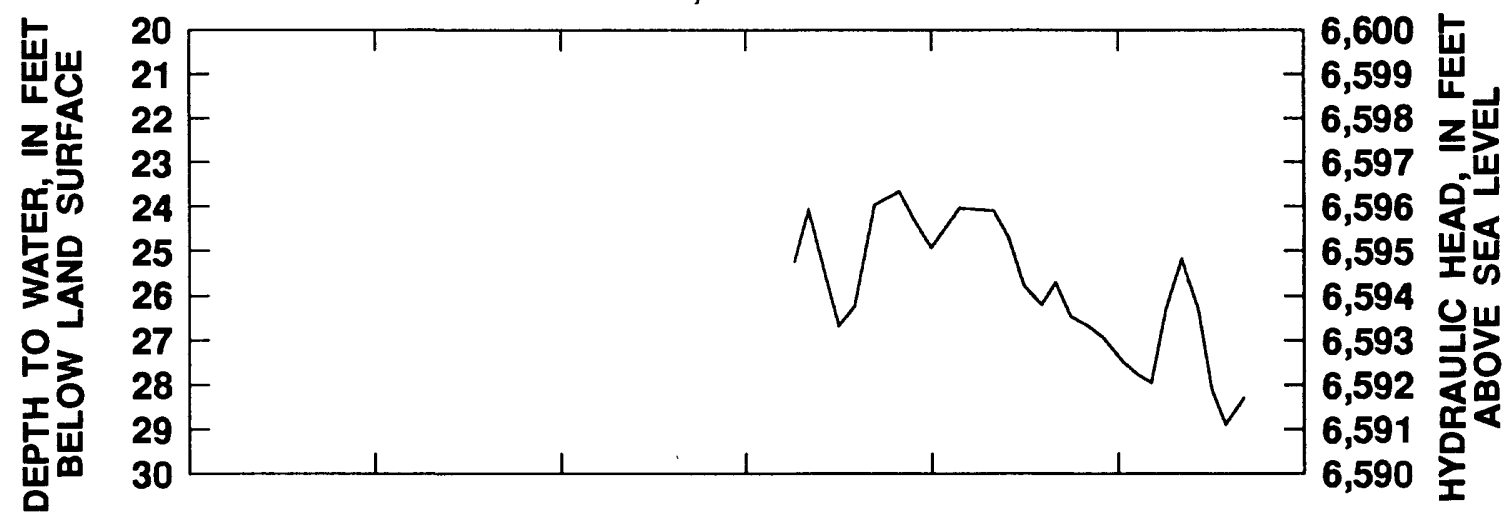

SITE 39, TIJERAS

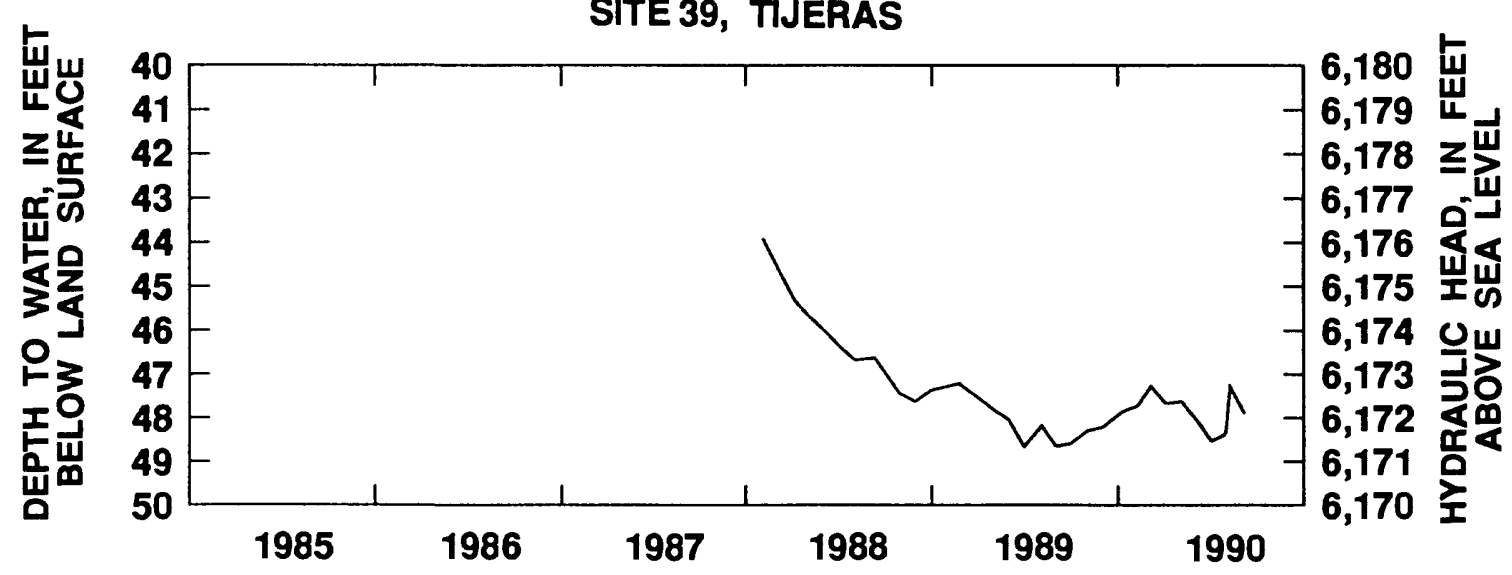

Figure 3.--Water-level data from selected wells and piezometers in the Albuquerque Basin (site location shown in figure 1) - Continued. 
SITE 40, SINK HOLE

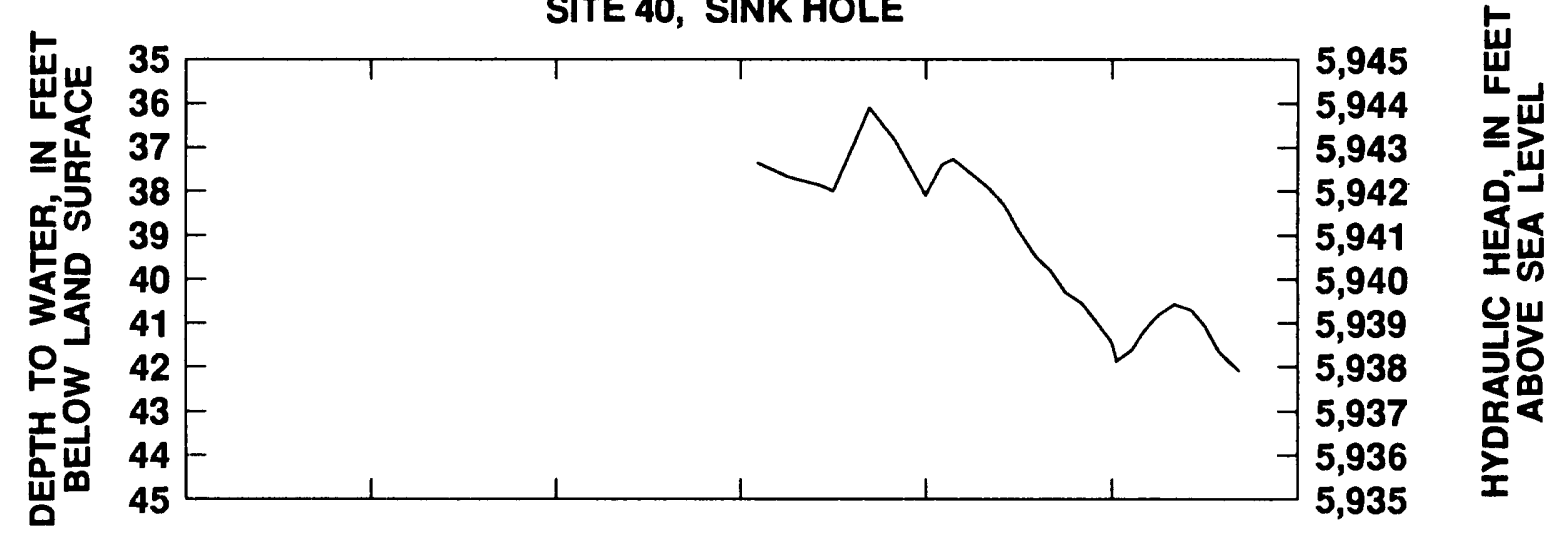

SITE 41, KAFB 5

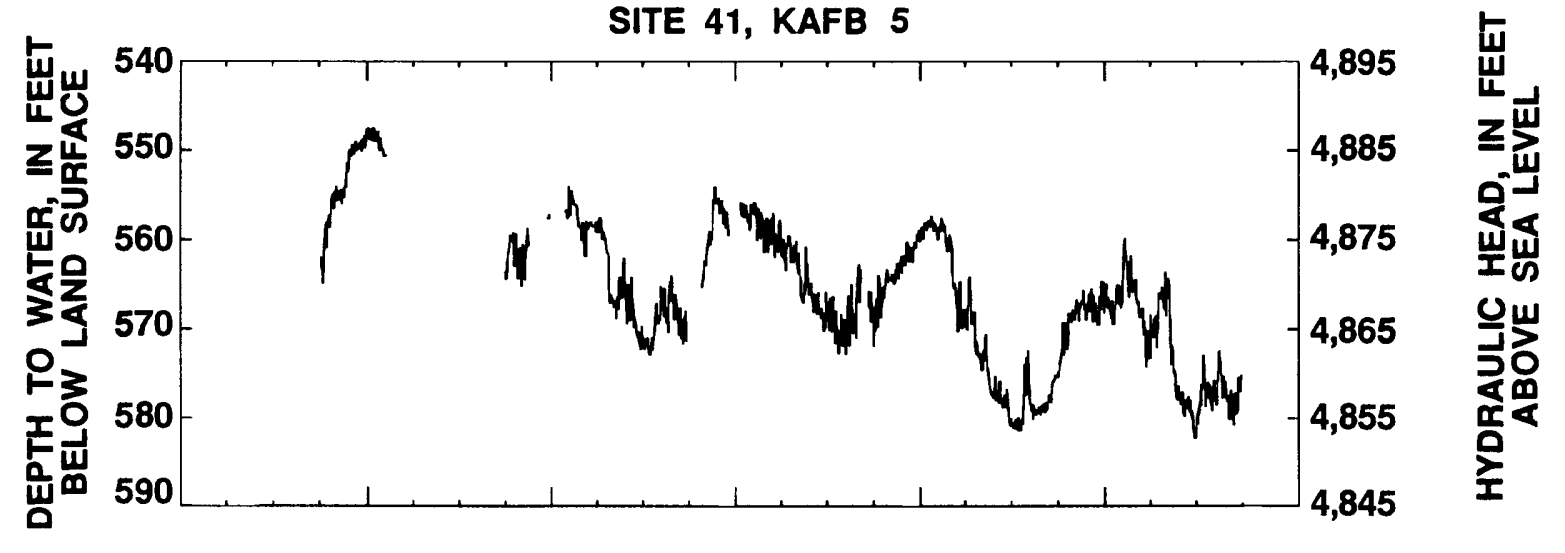

SITE 42, DEAD MAN'S CURVE

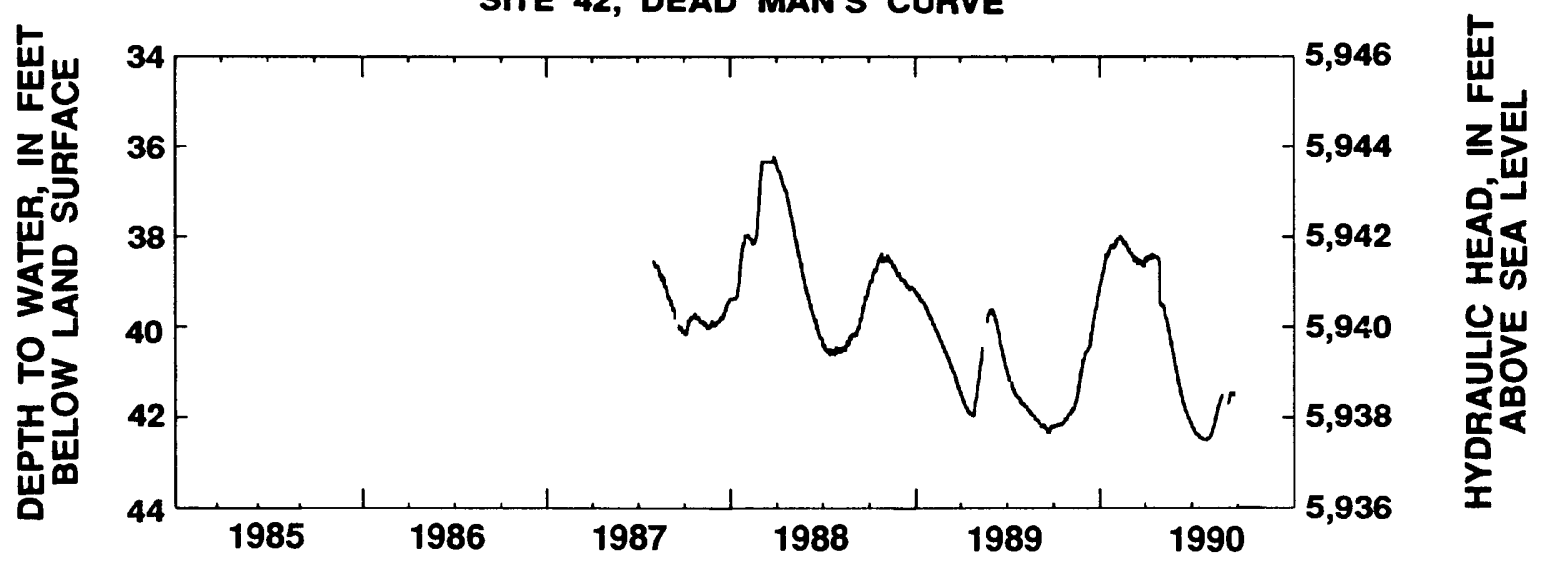

Figure 3.--Water-level data from selected wells and piezometers in the Albuquerque Basin (site location shown in figure 1) - Continued. 

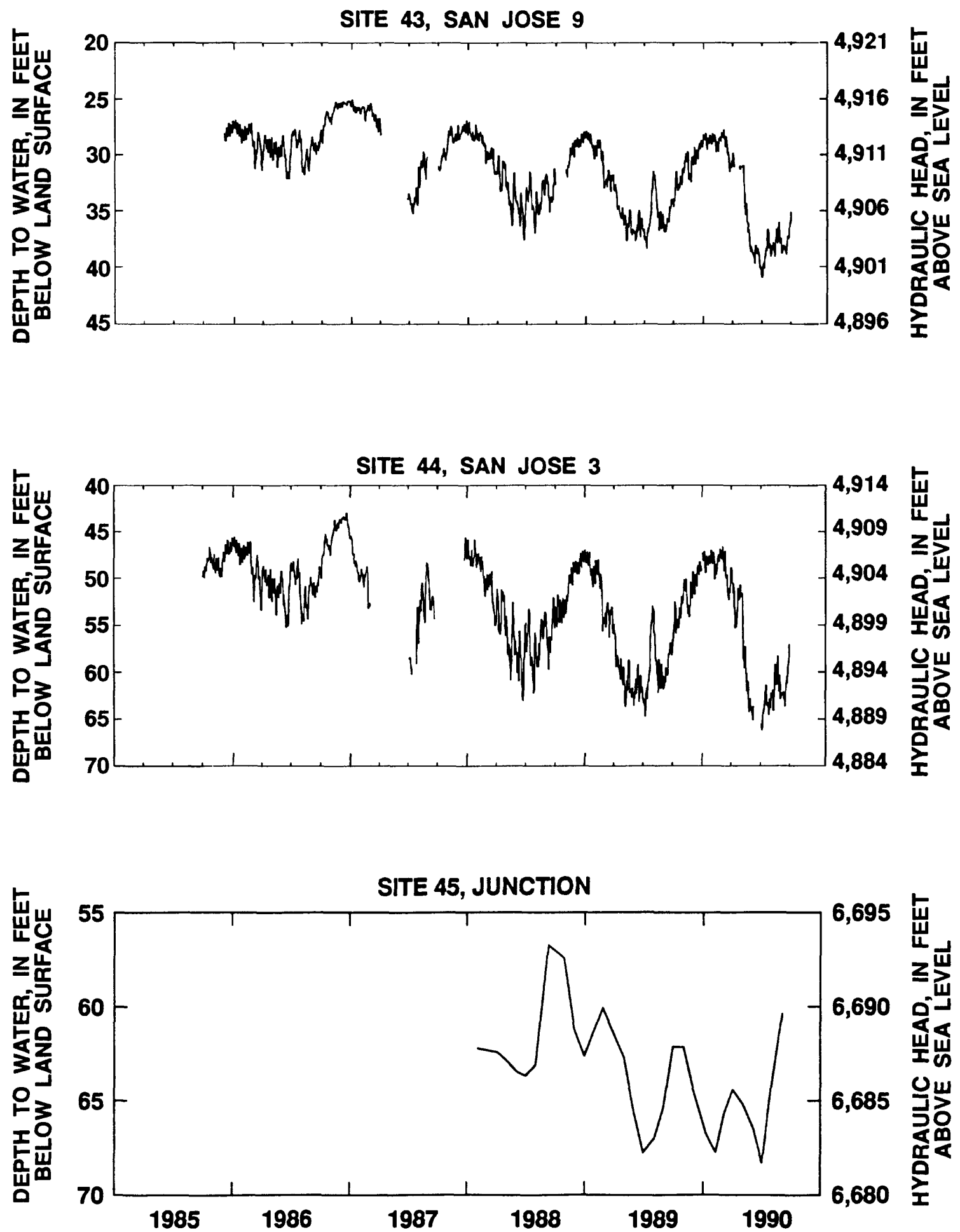

Figure 3.--Water-level data from selected wells and piezometers in the Albuquerque Basin (site location shown in figure 1 ) - Continued. 
SITES 46-48, WEST MESA 2
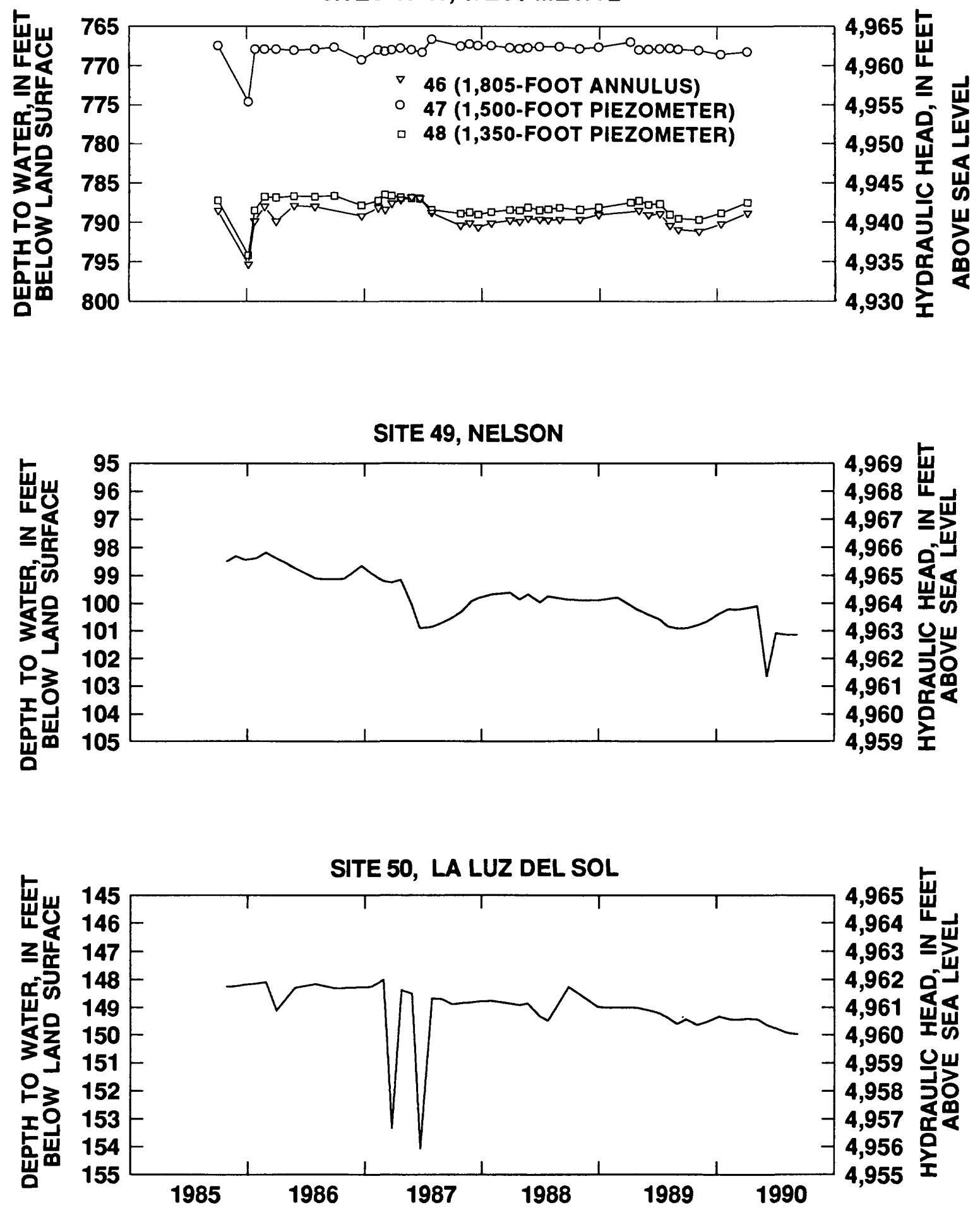

Figure 3.--Water-level data from selected wells and piezometers in the Albuquerque Basin (site location shown in figure 1 ) - Continued. 
SITES 51-53, MONTAÑO 1

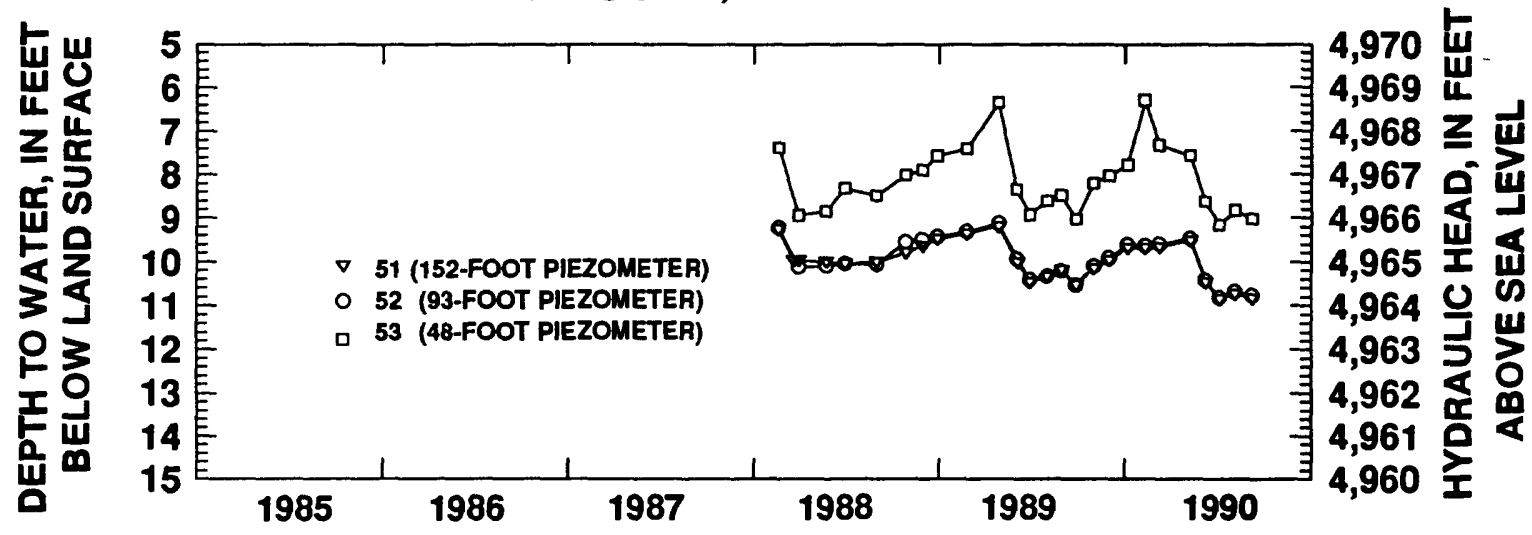

SITES 54-56, MONTAÑO 2
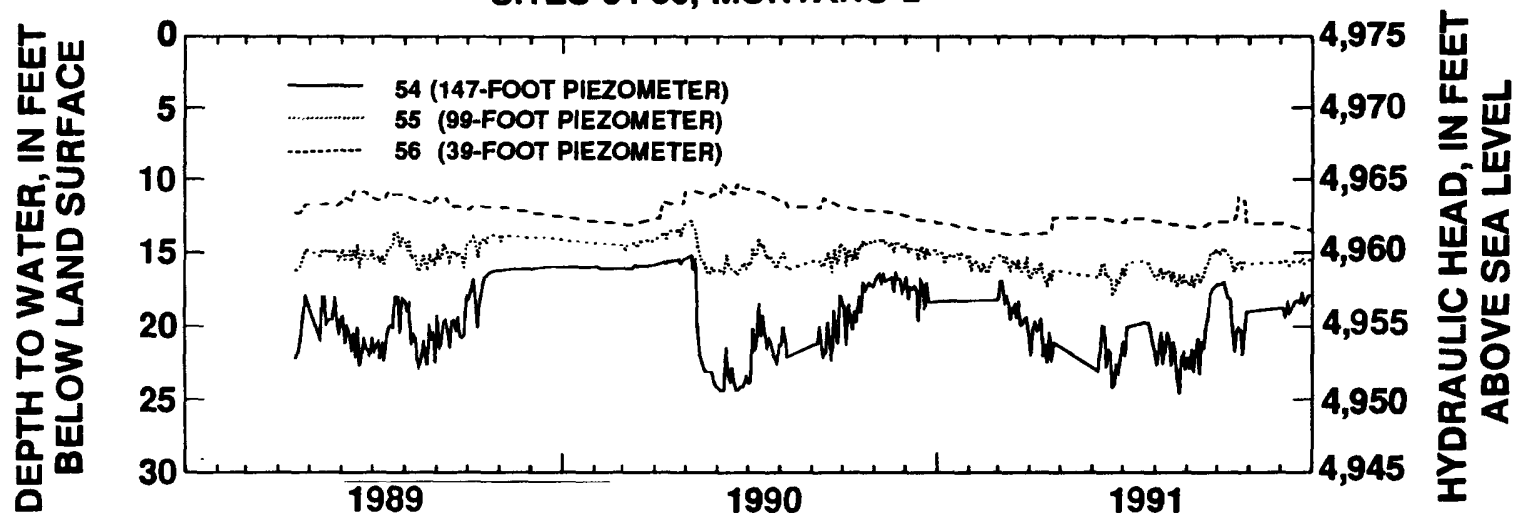

SITES 57-59, MONTAÑO 3

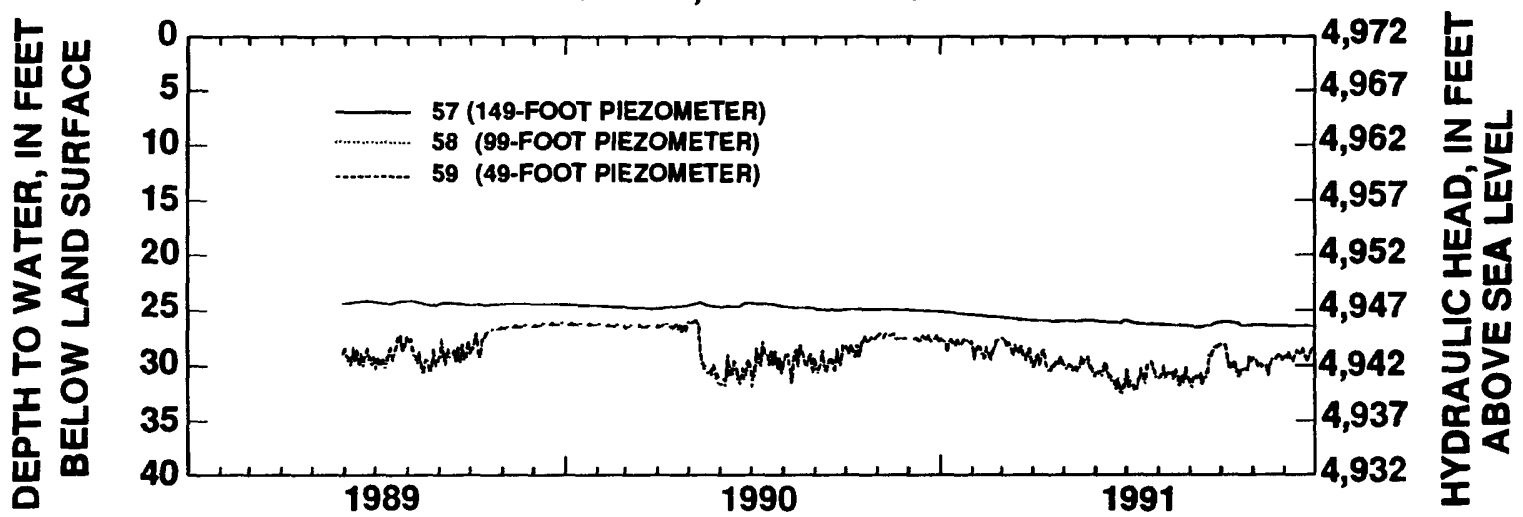

Figure 3.--Water-level data from selected wells and piezometers in the Albuquerque Basin (site location shown in figure 1) - Continued. 
SITES 60-62, MONTAÑO 4

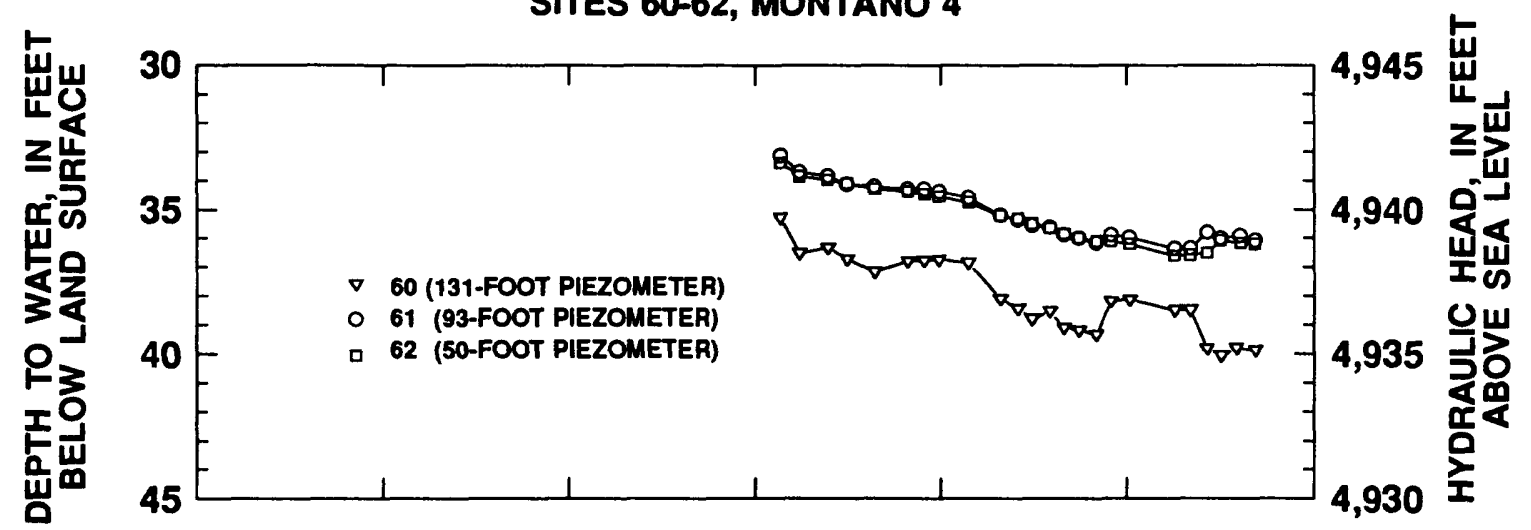

SITE 63, SHOEMAKER

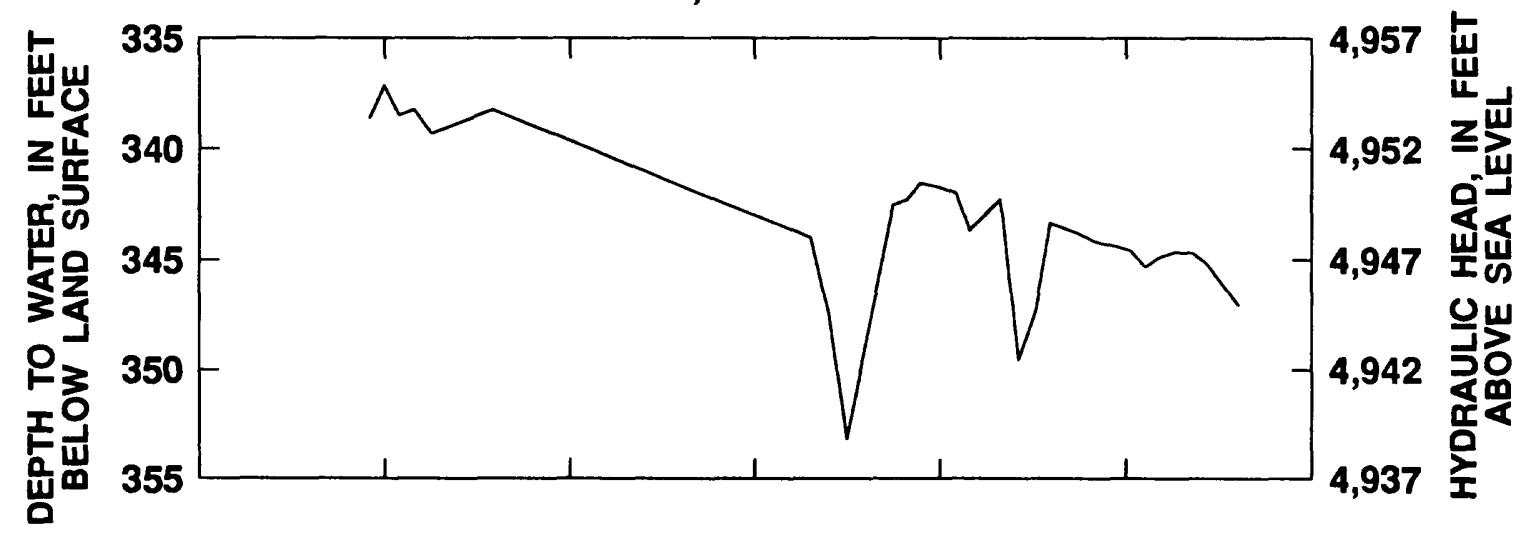

SITES 64-66, WEST MESA 3

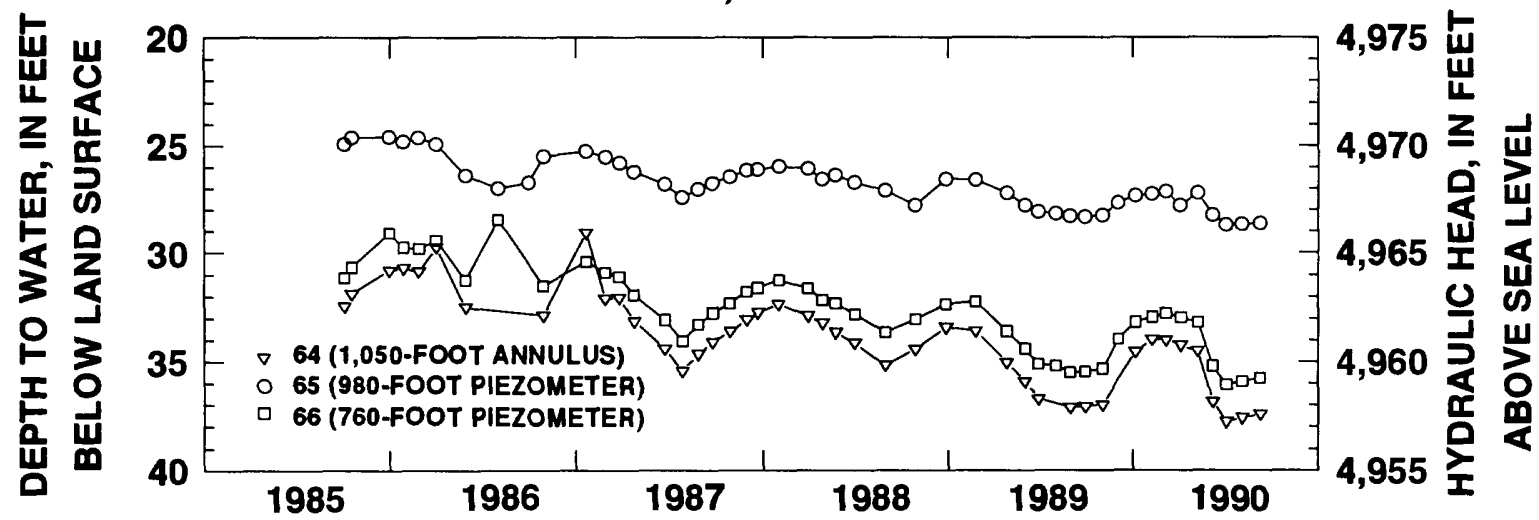

Figure 3.--Water-level data from selected wells and piezometers in the Albuquerque Basin (site location shown in figure 1) - Continued. 

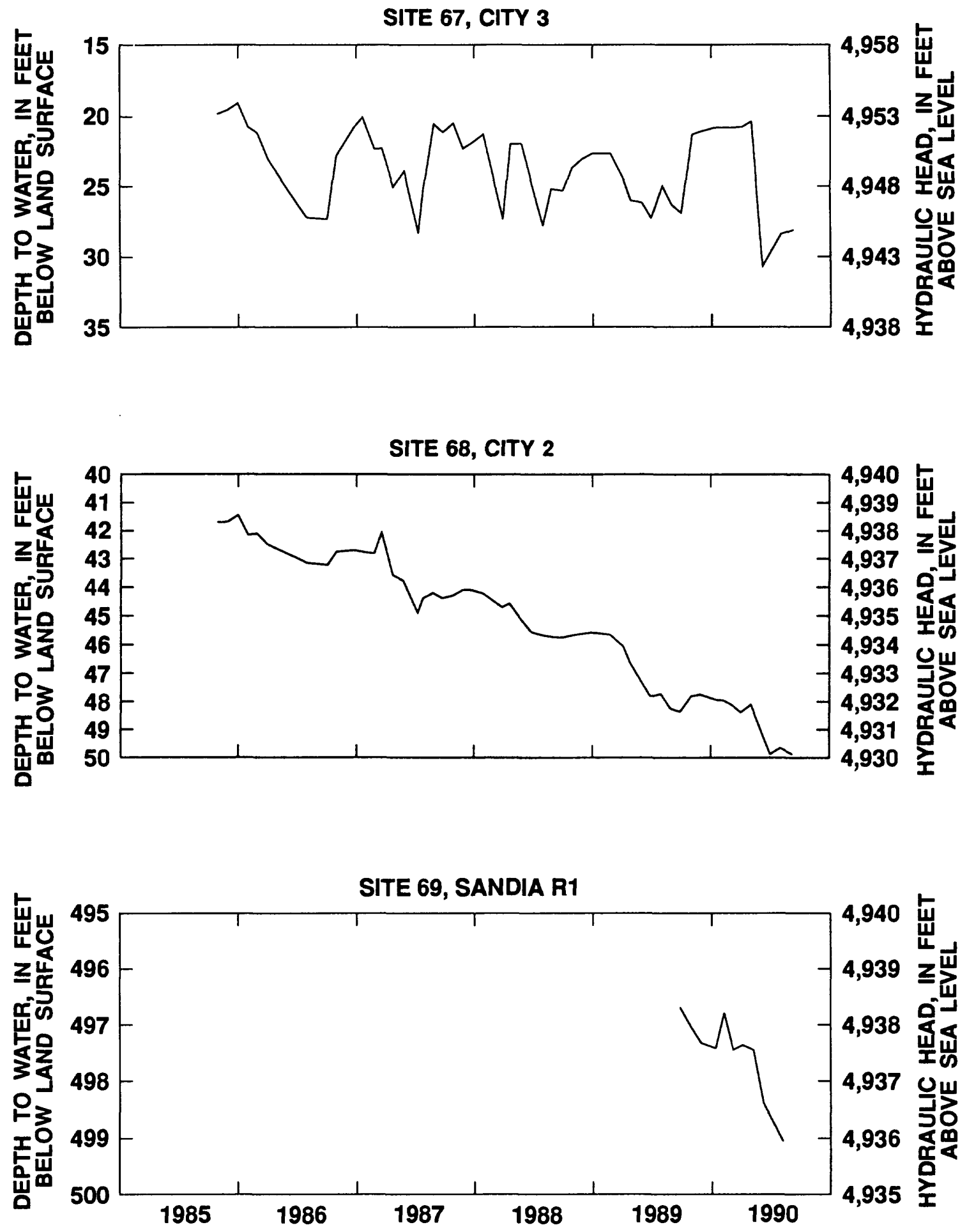

Figure 3.--Water-level data from selected wells and piezometers in the Albuquerque Basin (site location shown in figure 1 ) - Continued. 


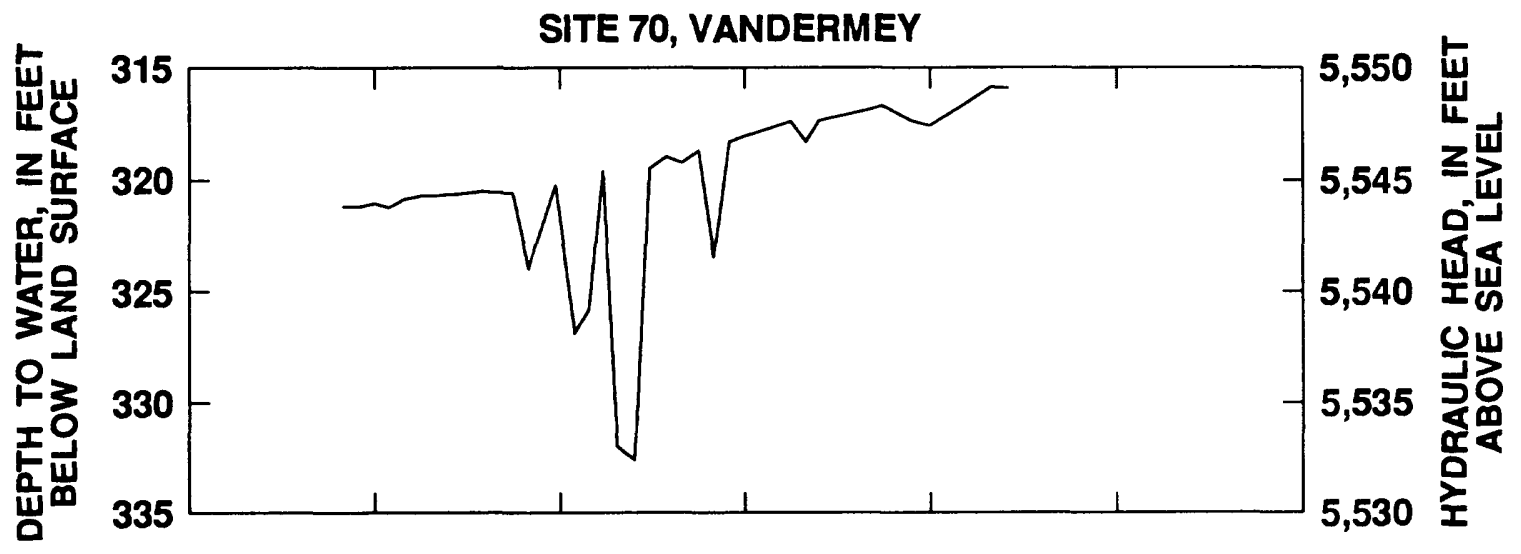

SITE 71, BETANIA
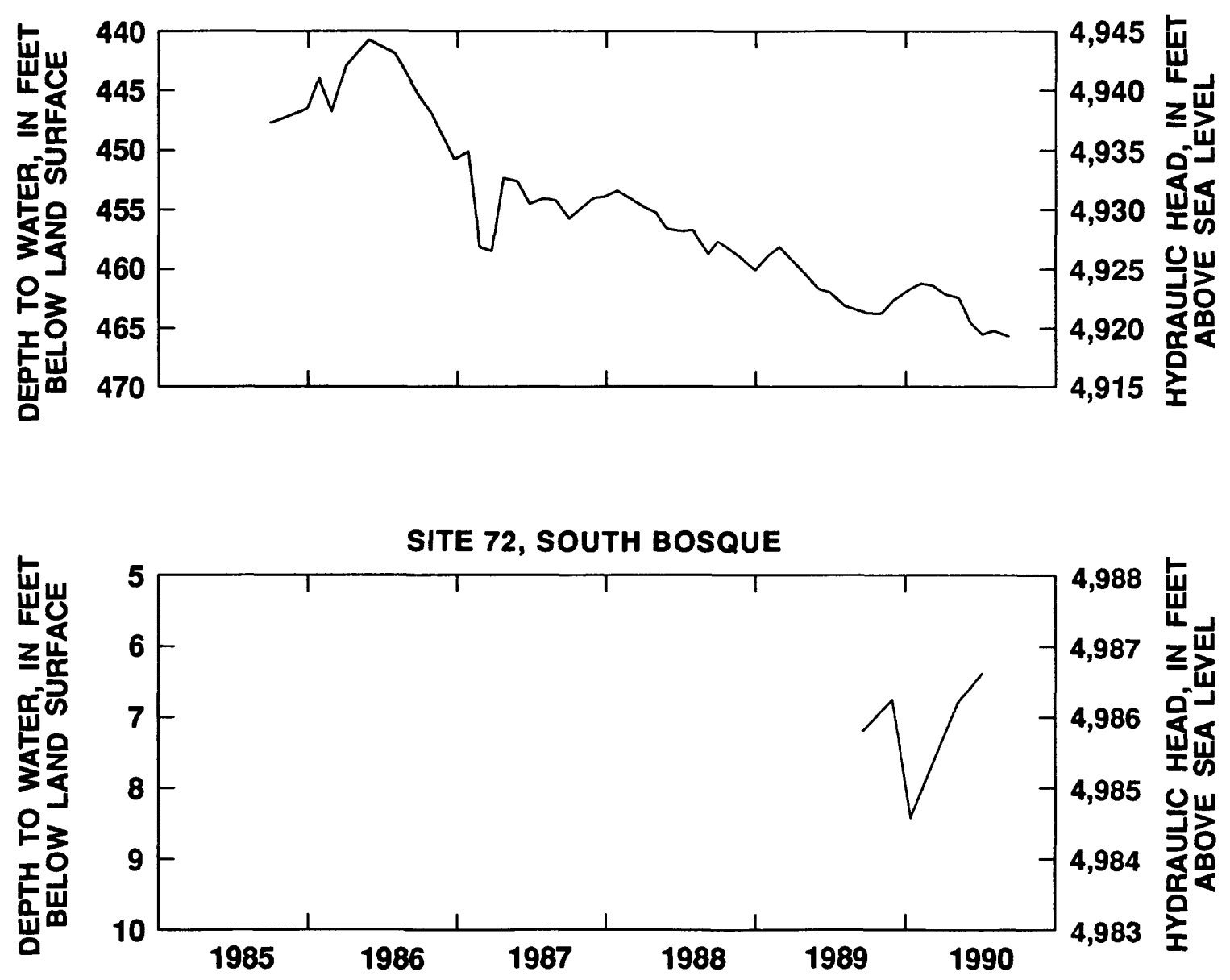

Figure 3.--Water-level data from selected wells and piezometers in the Albuquerque Basin (site location shown in figure 1) - Continued. 
SITE 73, MIDDLE BOSQUE
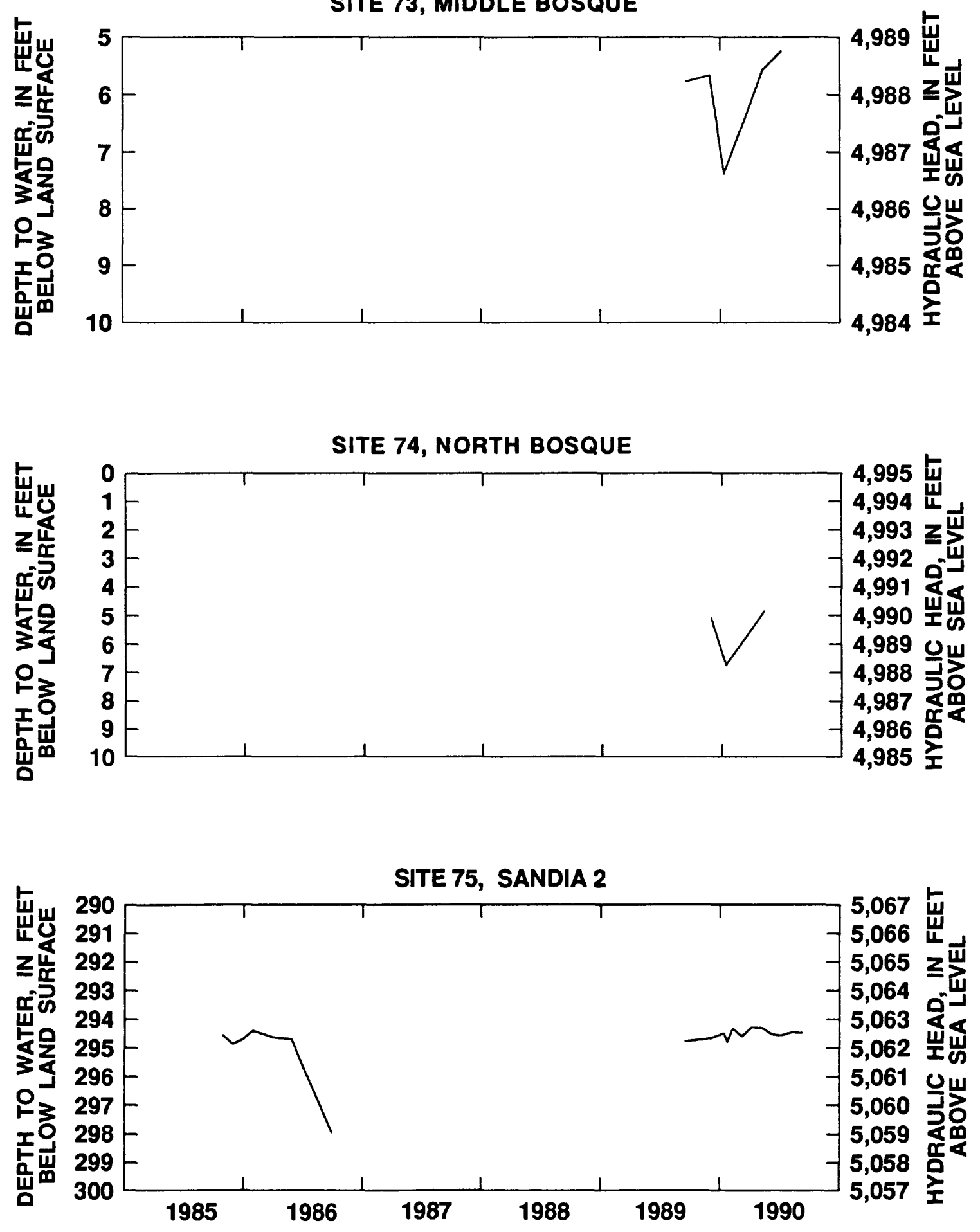

Figure 3.--Water-level data from selected wells and piezometers in the Albuquerque Basin (site location shown in figure 1) - Continued. 


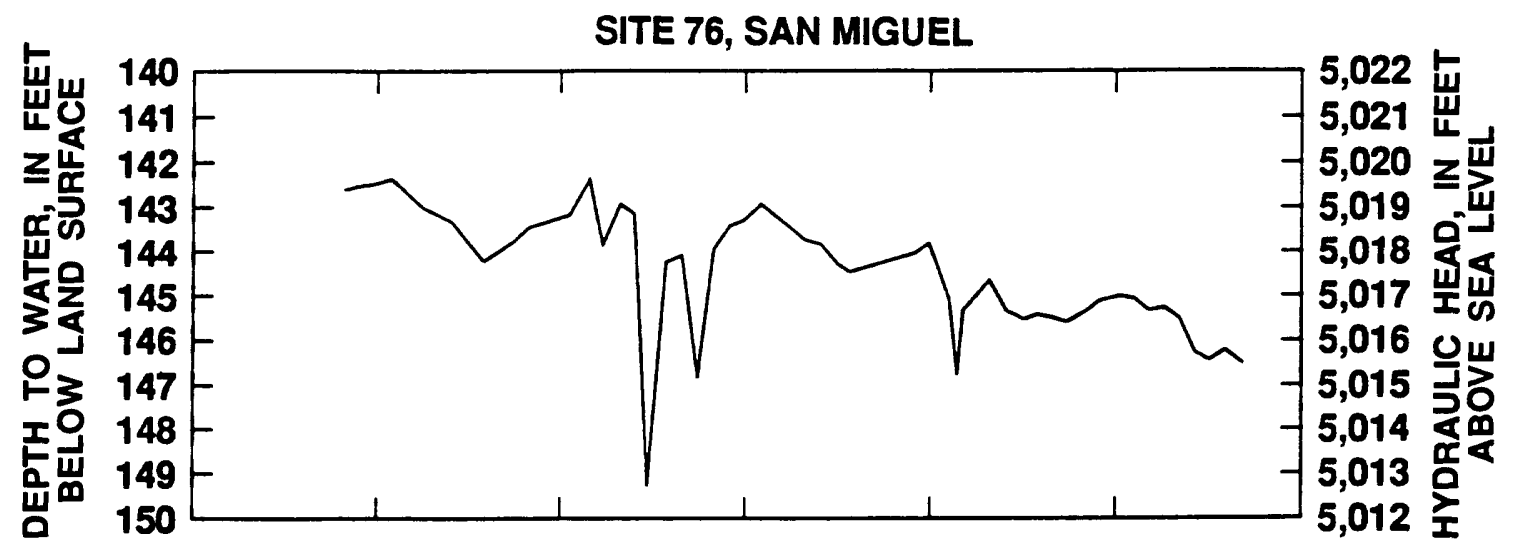

SITE 77 , SANTA ANA 2
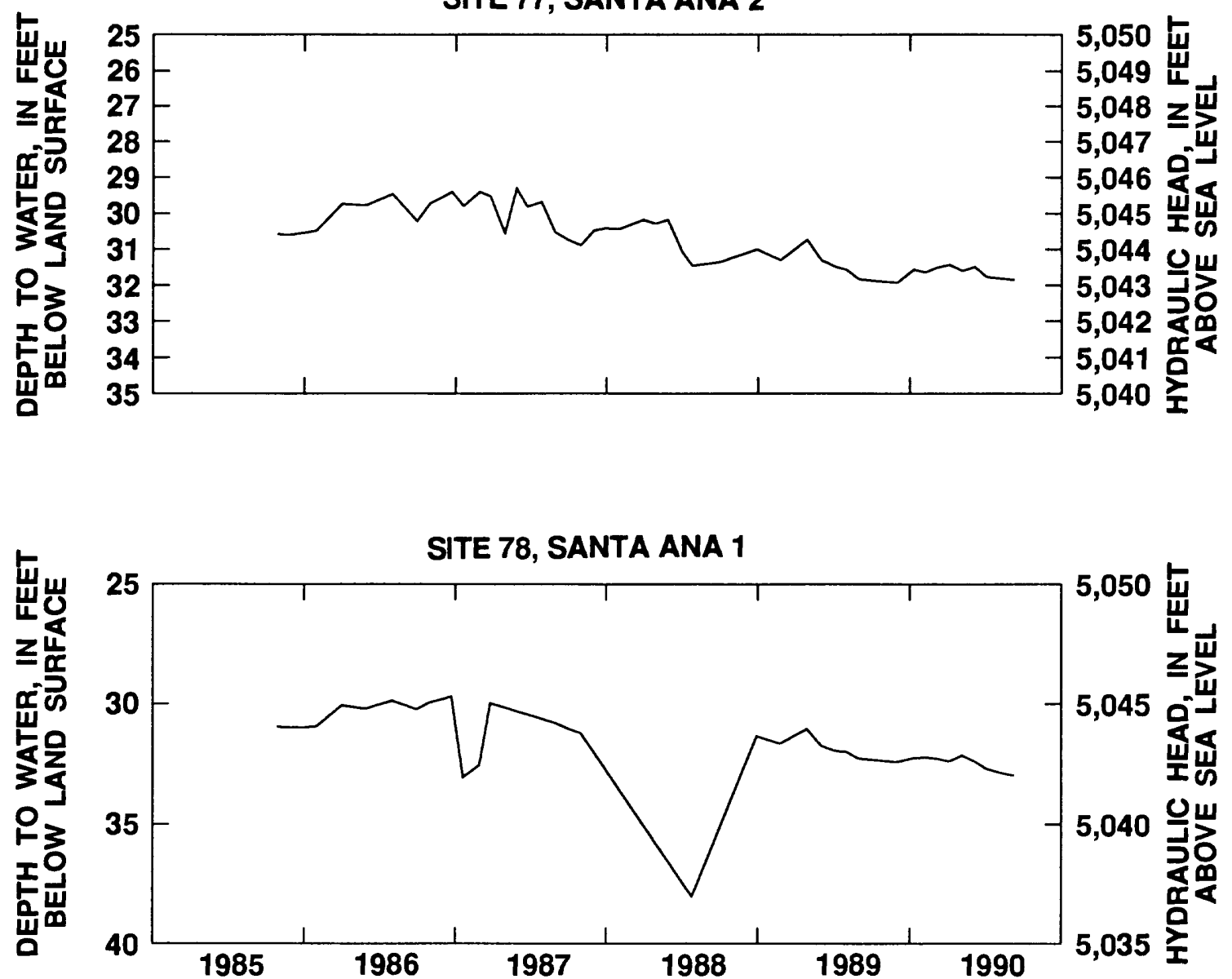

Figure 3.--Water-level data from selected wells and piezometers in the Albuquerque Basin (site location shown in figure 1) - Continued. 


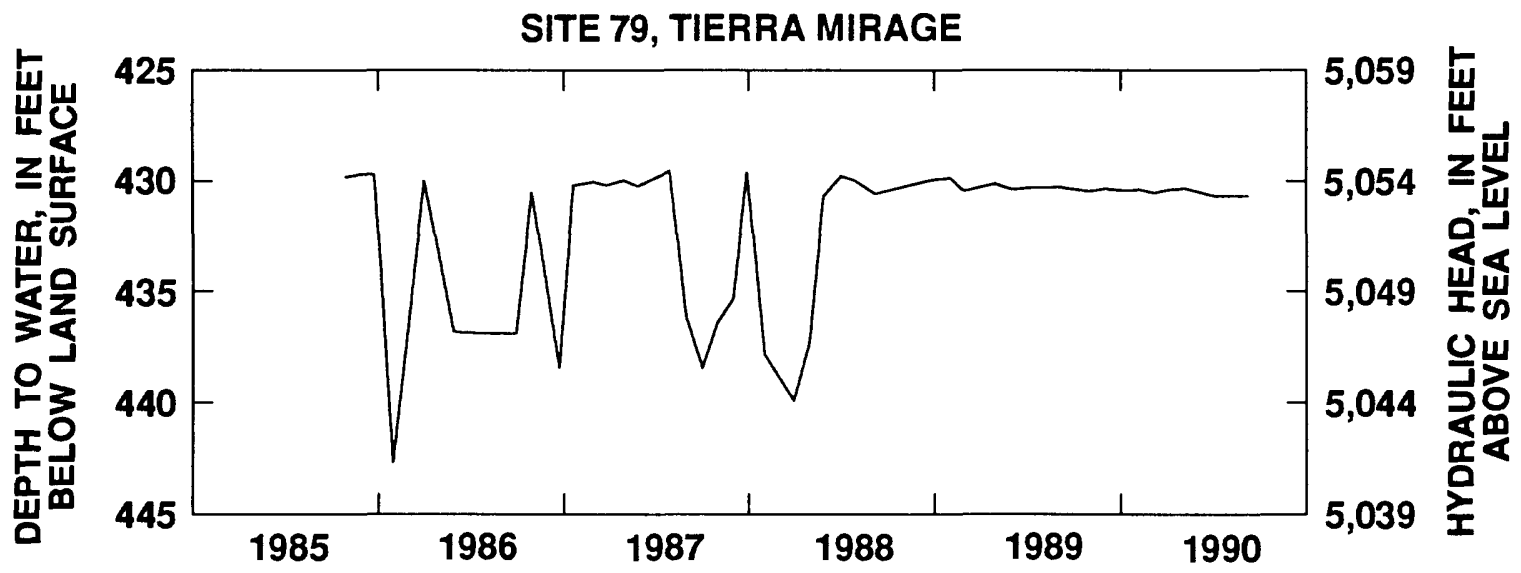

Figure 3.--Water-level data from selected wells and piezometers in the Albuquerque Basin (site location shown in figure 1 ) - Concluded. 